\title{
HEMATOLOGICAL AND BIOCHEMICAL ABNORMALITIES OF CANINE MAMMARY GLAND TUMORS CORRELATED TO THEIR HISTOPATHOLOGICAL TYPES AND SERUM BIOMARKERS.
}

\author{
SHAHENAZ M.H. HASAN*; NAHEAD F. ZAGHLOL*; SANAA A. EL-SHAMY ${ }^{* * * *}$ and \\ DINA K. LATTEEF ${ }^{* * * *}$ \\ * Clinical Pathology Department, Animal Health Research Institute, Alexandria Provincial Lab. \\ ***Bochemistry Department, Animal Health Research Institute, Alexandria Provincial Lab. \\ **** Pathology Department, Animal Health Research Institute, Alexandria Provincial Lab. \\ ***** Veterinary Medicine Province, Alexandria Governorate.
}

Email: afyfi@yahoo.com

Assiut University web-site: www.aun.edu.eg

\section{ABSTRACT}

Received at: $24 / 2 / 2015$

In the present study, we tried to evaluate the existence of a relationship between CA 15-3 serum levels and mammary tumors in dogs correlated with heamatobiochemical and histopathological pictures. Blood and tissue samples were obtained from 31 mammary tumors bearing dogs, in addition to 5 apparently healthy dogs. The results revealed that the values of CA15-3 in healthy dogs were lower than in human, equal to $\geq 1 \mathrm{u} / \mathrm{ml}$ but in mammary tumors bearing dogs rose to 7 $7.7 \mathrm{u} / \mathrm{ml}$. No relationship between tumor markers (CA15-3), tumor size, presence of ulceration or histopathological type of tumor were found. Microcytic hypochromic anemia and sometimes leukocytosis especially neutrophilia were present with tumors. Unfortunately, the serum values of CA15-3 rose to $17 \mathrm{u} / \mathrm{ml}$ in animals suffering from other diseases. Pathological picture of the tumors showed that malignant cancers were of the highest percentage than benign tumours and revealed several different types of malignant cancers. Mixed and complex carcinoma were the most prominent types of mammary gland tumors of dogs. Immunohistochemical staining of estrogen receptors (ER) and progesterone receptors (PR) in canine mammary gland tumors showed benign fibrocystic disease positive for ER and PR. Tubulopapillary carcinoma was positive for (ER) and (PR). Anaplastic giant carcinoma was positive for (PR) and negative for (ER). Mucinous carcinoma was positive for (ER) negative for (PR). Complex carcinoma showed very weak positive staining for (ER) negative (PR). Mixed Carcinoma was negative for both (PR) and (ER).

Key words: Canine mammary neoplasia, Serum biomarker, Hematology, Histopathology, Immunohistochemstry and Biochemistry.

\section{INTRODUCTION}

Although veterinary practice need advances in biomedical research in their own right, the consideration of companion animals as good comparative models for human disease saw the emergence of the "one medicine" concept. The concept of "one medicine" rests on the translation between human and veterinary medicine in both directions (Breen, 2009 and Rivera, 2010). The domestic dog has emerged as an ideal model for gene mapping of human complex diseases, as it has a spectrum of diseases similar to that in man and also an advantageous population structure (Sutter and
Ostrander, 2004; Sutter et al., 2007; Karlsson and Lindblad- Toh, 2008).

It is estimated that one of four dogs greater than 2 years of age dies of cancer (Rivera, 2010). In some animal cancers, there also appears to be the same genetic changes associated as in humans (MatharooBall et al., 2008).

In human breast cancer and other malignancies, serum tumor markers play an important role in patient management (Seker et al., 2003 and Molina et al., 2005). Tumor cells display protein molecules on their surfaces, called tumor-associated antigens and may be present in higher concentration than usual in other 
tissues, serum, urine or body fluids of patients with cancer. Thus, the elevation of these markers may be helpful in early diagnosis, determining prognosis following a course of treatment, predicting the response or resistance to specific therapies and surveillance after primary surgery (Duffy et al., 2004 and Al-Azawi et al., 2006).

Carbohydrate antigen (CA) $15-3$ is a large transmembrane glycosylated molecule aberrantly overexpressed in many adenocarcinomas in an underglycosylated form and then shed into the circulation (Hayes et al., 1985 and Perey et al., 1992).

Itoh et al. (2009) reported that tumor-bearing dogs had higher leukocytic counts than normal dogs increased as the tumors became more advanced.

It thought that the complete blood cell count can provide valuable diagnostic and prognostic information when coupled with a thorough physical examination. However, little work has been carried out in cancer biomarker identification in animals. The recent dramatic advances in molecular medicine, genomics, proteomics and translational research will allow biomarker identification which may provide the best strategies for veterinarians and clinicians to combat disease by early diagnosis and administration of effective treatments.

Mammary tumors are the most prevalent neoplasms in female dogs (Lana et al., 2007). According to the histological diagnosis, canine mammary tumors (CMT) are heterogeneous in their pathological features and clinical behavior (Nieto et al., 2000).

There are some recognized, well-accepted prognostic factors of malignant mammary tumors in dogs, such as tumor size, lymph node status, distant metastasis, histologic type, histologic malignancy grade, degree of nuclear differentiation and proliferative activity (Misdorp et al., 1999; Misdorp, 2002 and Martin et al., 2005).

Immunohistochemical method is a procedure to visualize and differentiate between tissue components using antigen-antibody complex basis. Tonitil et al. (2009) reported the correlation between steroid receptors, estrogen receptor and progesterone receptor, and canine mammary gland tumors. ER and PR expression in breast epithelial cells is considered a marker for risk of developing breast cancer and for preventive intervention (Fabian et al., 2005, Ferretti et al., 2007). Estrogen receptors (ER) are expressed by more than $50 \%$ of canine mammary gland tumors (Martin et al., 2005; Yang et al., 2006 and Lana et al., 2007). (This technique provides valuable information in terms of the location and the determination of tumor type), Immunohistochemical techniques have critical role to distinguish these cells and may allow accurate diagnosis of canine mammary tumors, however, this method cannot detect the early stage of canine mammary tumour (Bergman, 2003 and Gama et al., 2003).

Therefore, this study aimed to evaluate serum values of CA 15-3 mammary tumor marker in normal healthy, diseased non tumor bearing, and tumor bearing dogs in local reared mixed breeds of dogs in Egypt correlated with expression of ER, and PR, in neoplasm by immunohistochemistry with hematological, biochemical abnormalities and histopathology, record the incidence, criteria of malignancy and differentiate the simple tumor from the complex or mixed tumor of canine mammary gland carcinoma.

\section{MATERIALS and METHOD}

\section{Animals:}

Dogs in our study were mixed breeds German shepherd, Griffin dog, and Rott-Weiller, aged 3-10 years old. The non tumor bearing dogs were apparently healthy and in good healthy condition without any complain from their owners. The samples were collected after the owners permissions during dogs routine chick up tests. Most of the tumors bearing dogs were brought to the clinic in a late stage.

\section{Methods:}

Blood and serum samples were collected from 30 female dogs bearing nodules on the site of mammary gland. Additional 5 samples were collected from healthy female dogs and did not show any mammary lesions during routine check-up (after the permission of the dogs' owners).

The blood samples were collected on EDTA as anticoagulant and used immediately to measure erythrocytic count (RBCs) using improved Neubauer Haemocytometer and Gower,s fluid as a diluting fluid according to Feldman et al. (2000). Total leukocytic count (WBCs) were done using improved Neubauer Haemocytometer with turkey's solution according to Jain (1993). PCV\% was determined by using microhematocrite centrifuge and capillary tubes method according to Thrall et al. (2004). The blood hemoglobin was estimated using the cyanomethemoglobin colorimetric technique according to VanKampan and Zijlistra, (1961). The values of Mean Corpuscular Volume (MCV), Mean Corpuscular Hemoglobin (MCH) were calculated by standard formula according to Dacie and Lewis, (1977). The prepared fixed thin blood films were stained with Giemsa stain. The film then examined for morphological changes in RBCs and WBCs according to Thrall et al. (2004). The percentage values of differential leukocytic count were then calculated according to Jain, (1993). 
Another blood samples were collected without anticoagulant to obtain serum. The serum were either used immediately or kept frozen until used for measurement of Serum aspartate aminotransferase (AST), Serum Alanin aminotransferase (ALT) activities determined according to Reitman and Frankels, (1957). Serum urea level was determined using kits provided by bioMerieux according to Patton and Crouch (1977). Serum creatinine was determined using kits provided by bioMerieux according to Husdant and Rapaport (1958) Serum total protein were determined according to Doumas et al. (1981), albumin was determined according to Doumas et al. (1971). CA 15-3 levels were determined by the use of the monoclonal antibodies $115 \mathrm{D} 8$ and DF3 in a sandwich assay using Cobas ${ }^{\circledR}$ CA15-3 II and a kit for human diagnostic oncology (Fujirebio Diagnostics ${ }^{\circledR}$ ) according to the manufacturer's protocol. Values were expressed as Units/ml (U/ml). We used commercially available kits for human medicine. These markers are not currently available in veterinary medicine. 31 tissue samples were obtained from female dogs with solitary and multiple nodules sumitted simultaneously with other site of body during surgery in veterinary clinics.

\section{Histopathological Examination:}

Surgical specimens of canine mammary tissue were submitted to the Department of pathology, animal health research institute of Alexandria, from 2012 to 2014 for diagnostic purposes. The majority of specimens were from animals surgically treated at Pet Department Alexandria directorate of Veterinary Medicine or Clinics of the private practices. 31 tissues specimens were fixed in $10 \%$ buffered formalin, routinely processeced Samples were then embedded in paraffin wax and $5 \mu \mathrm{m}$ sections were prepared and stained with hematoxylin and eosin (Bancroft et al., 1996).

\section{Immunohistochemistry:}

Tumor sections were processed according to standard protocols at general health research institute in Alexandria using thermo fisher scientific (Ultravision Large volume detection system; Anti-polyvalent, (HRP). Tissue sections were deparaffinized, rehydrated and to reduce nonspecific background staining due to endogenous peroxidae were incubated in hydrogen peroxide for 10-15 minutes and then washed by phosphate buffer salin. Ultra V Block was applied and incubates for 5minutes at room temperature to block non specific background staining. Primaries antibody were applied and incubated according to manufacture protocol, after washing 4 times in buffer Biotinylated goat Antipolyvalent were applied and incubated for 10 minutes at room temperature and then washed 4 times in buffer. Sterptavidin peroxidae and incubate for 10 minutes at room temperature and rinse 4 times in buffer. Incubated with peroxidae-compatible chromogen of choice according to manufacturers recommendations. Slides were counterstained with Harris haematoxylin, Different fields were observed and immunopositive reactions were demonstrated by the presence of brown nuclear staining.

\section{5- Statistical analysis:}

The statistical analysis of measured values was performed according to the one-way ANOVA variance test. The differences were considered to be statistically significant at $\mathrm{P}<0.05$ Data were analyzed by computer using SPSS version 16.0 for windows. (Statistical Package for the Social Sciences Inc, Chicago, Illinois).

\section{RESULTS}

\section{CA 15-3 marker in serum:}

The results of CA15-3 tumor marker values (table 1) revealed that, the apparently health non-tumor bearing dogs were $\geq 1 \mathrm{U} / \mathrm{ml}$. The mean value \pm SD of CA 15-3 tumor marker in tumor bearing dogs was 7.2 $\mathrm{U} / \mathrm{ml} \pm 0.18$. In seventy seven percent of the cases the CA15-3 value was $7.1 \mathrm{U} / \mathrm{mL}$, in $16.1 \%$ was $7.5 \mathrm{U} / \mathrm{mL}$ and in $3.2 \%$ of the cases were $7.7 \mathrm{U} / \mathrm{mL}$.

The value of CA 15-3 tumor marker in non tumor bearing dog with other disease condition were 17 and $8 \mathrm{U} / \mathrm{ml}$.

\section{Heamatological and biochemical examinations:}

The results of hematological and biochemical examinations as demonstrated in table (2) revealed microcytic hypochromic anaemia(phtola) to be present in the most of the cases. RBCs characterized by poikilocytosis and anisocytosis (photo. 1), beside leukocytosis were detected in some cases, especially neutrophilia. All 31 cases had normal levels of AST, ALT, urea and creatinine.

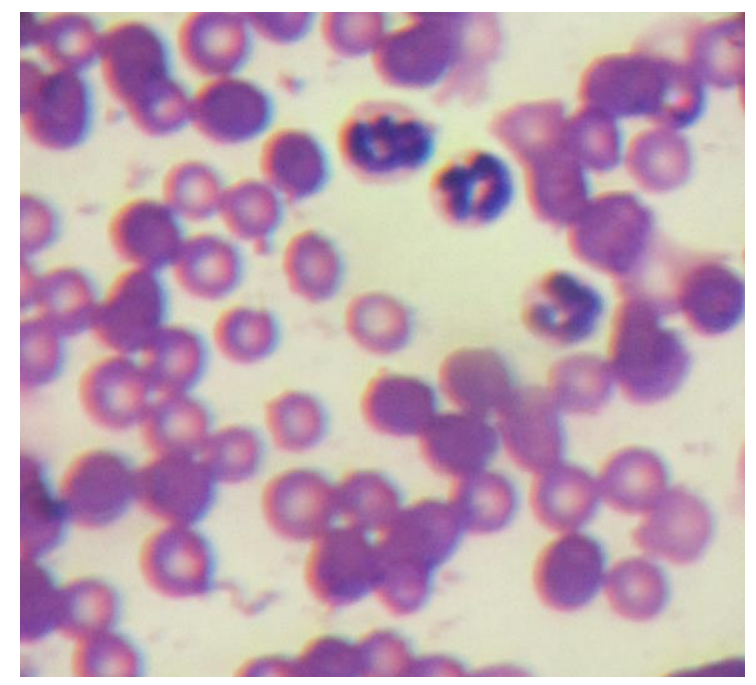

Photo 1 :(a) Tumor bearing dog of (Griffin 10 years) showing microcytic hypochromic anemia, anisocytosis and pikilocytsis. Giemsa stain X1000 
3. Results of non tumor bearing dog with other disease conditions:

The results of hematological and biochemical examination of tumor bearing dogs table (3) revealed presence of heamolytic anemia (photo 1b) in Black pit-bull dog (50 days old). Presence of hemolysis in serum interfered. The measurements of serm AST, ALT, urea and creatinine.

The German shepherd dogs showed macrocytic anemia, in addition to increased serum levels of
$\operatorname{AST}(72 \mathrm{u} / 1)), \operatorname{ALT}(95 \mathrm{u} / \mathrm{l})$ marked hypoprotenemia and hypo-albumenemia this was indicated by decreased serum total protein $(4.5 \mathrm{~g} / \mathrm{dl})$, serum albumin $(2.8 \mathrm{~g} / \mathrm{dl})$, and albumin globulin ratio (1.6 ).

Serum urea and serum creatinin levels were within normal range $(15.3 \mathrm{mg} / \mathrm{dl})$ and $(0.54 \mathrm{mg} / \mathrm{dl})$ respectively. So, we thought may be liver problem.

Table 1: The results (Values are mean $\pm \mathrm{SD}$ ) of CA15-3 tumor marker values. The mean differences are significant at 0.05 level:

\begin{tabular}{lccc}
\hline Parameter & Healthy dogs & tumor bearing dogs & $\begin{array}{c}\text { non tumor bearing dog } \\
\text { with other disease } \\
\text { condition }\end{array}$ \\
\hline $\mathbf{C A 1 5 - 3 ~ U / m l ~}$ & $\mathbf{\geq 1}$ & $\mathbf{7 . 2} \mathbf{+ 0 . 1 8}$ & $\mathbf{8 - 1 7}$ \\
\hline A & & & \\
\hline
\end{tabular}

$\mathrm{A} \mathrm{p}<0.05$ tumor bearing dogs compared with Healthy dogs

Table 2: The results (Values are mean \pm SD) of hematological and biochemical examinations. The mean differences are significant at 0.05 level.

\begin{tabular}{|c|c|c|}
\hline Parameters & $\begin{array}{l}\text { tumor bearing dogs (the mean } \\
\text { values } \pm \text { SD) }\end{array}$ & Healthy dogs(the mean values \pm SD) \\
\hline RBCs count $/ 10 \% / \mu \mathrm{l}$ & $4.6 \pm 0.3^{\mathrm{A}}$ & $6.9 \pm 0.9$ \\
\hline $\mathrm{Hb} / \mathrm{g} / \mathrm{dl}$ & $9.6 \pm 0.3^{\mathrm{A}}$ & $16.2 \pm 1.3$ \\
\hline PCV\% & $29.9 \% \pm 1.8^{\mathrm{A}}$ & $45.58 \% \pm 3.9$ \\
\hline $\mathrm{MCV} / \mathrm{fl}$ & $64.9 \mathrm{fl} \pm 4.9$ & $66.4 \pm 3.5$ \\
\hline MCH/pg & $20.9 \mathrm{pg} \pm 1.5$ & $23.7 \pm 1.9$ \\
\hline WBCs count $10^{3} / \mu \mathrm{l}$ & $15.000-30.000 / \mu 1$ & $9.960 \pm 7.6$ \\
\hline S.GOT u/l & $26.8 \pm 6.9$ & $22.8 \pm 2.4$ \\
\hline S.GPT u/l & $34.75 \pm 6.8$ & $28.8 \pm 3.6$ \\
\hline Urea mg/dl & $19.02 \pm 3.8$ & $18.37 \pm 4.3$ \\
\hline Creatinine mg/dl & $0.6 \pm 0.18$ & $0.56 \pm 0.1$ \\
\hline
\end{tabular}

A $p<0.05$ tumor bearing dogs compared with Healthy dogs

Table 3: The results of hematological and biochemical examinations of non tumor bearing dog with other disease condition.

\begin{tabular}{lll}
\hline Parameters & black pitbull 50 days & German shepherd 3years \\
\hline RBCs count $/ \mathbf{1 0} / \boldsymbol{\mu l}$ & 2.9 & 4 \\
\hline $\mathbf{H b} / \mathbf{g} / \mathbf{d l}$ & 5.3 & 9 \\
\hline $\mathbf{P C V \%}$ & 15.6 & 35 \\
\hline $\mathbf{M C V} / \mathbf{f l}$ & 52.8 & 87.5 \\
\hline $\mathbf{M C H} / \mathbf{~ p g}$ & 17.8 & 22.5 \\
\hline WBCs count/ $\boldsymbol{\mu l}$ & 17000, lymphocytosis & 14000 \\
\hline S.GOT u/l & $10 \mathrm{u} / \mathbf{l}$ & $72 \mathrm{u} / \mathrm{l}$ \\
\hline S.GPT u/l & $12 \mathrm{u} / \mathbf{l}$ & $95 \mathrm{u} / \mathrm{l}$ \\
\hline Urea $\mathbf{~ m g / d l}$ & $29 \mathrm{mg} / \mathrm{dl}$ & $15.3 \mathrm{mg} / \mathrm{dl}$ \\
\hline Creatinine $\mathbf{~ m g / d l}$ & $0.92 \mathrm{mg} / \mathrm{dl}$ & $0.54 \mathrm{mg} / \mathrm{dl}$ \\
\hline
\end{tabular}


Table 4: The results scoring type of tumor, number, age, breed of animal, cell of origin, percent of incidence and tumor marker value $\mathrm{U} / \mathrm{ml}$ in canine mammary tumour.

\begin{tabular}{|c|c|c|c|c|c|c|}
\hline Type of tumor & No & Age & Breed & Cell of origin & $\%$ & $\begin{array}{l}\text { Tumor } \\
\text { marker } \\
\text { U/ml }\end{array}$ \\
\hline Solid tubular & & & & ductal epithelial cells & & \\
\hline & 4 & $3-10$ years & Griffin & & $12.9 \%$ & 7.1 \\
\hline $\begin{array}{l}\text { Tubulopapill-ary } \\
\text { carcinoma }\end{array}$ & 3 & 4-7 years & Griffin & $\begin{array}{l}\text { Lobular ducts } \\
\text { epithelial cells }\end{array}$ & $9.7 \%$ & 7.0 \\
\hline $\begin{array}{l}\text { Anaplastic giant } \\
\text { cell carcinoma }\end{array}$ & 4 & 3-10years & $\begin{array}{l}\text { Germen } \\
\text { shepherd }\end{array}$ & Undifferentiate cells & $12.9 \%$ & 7.1 \\
\hline $\begin{array}{l}\text { Mucinous } \\
\text { carcinoma }\end{array}$ & 1 & 5 years & Rot willer & $\begin{array}{l}\text { connective tissue, } \\
\text { myoepithelial cells }\end{array}$ & $3.2 \%$ & 7.1 \\
\hline $\begin{array}{l}\text { Mixed mammary } \\
\text { carcinoma }\end{array}$ & 12 & $3-10$ years & Griffin & $\begin{array}{l}\text { mesenchymal, } \\
\text { myoepithelial cells }\end{array}$ & $38.7 \%$ & 7.1 \\
\hline $\begin{array}{l}\text { Complex } \\
\text { Carcinoma }\end{array}$ & 5 & $5-7$ years & $\begin{array}{l}\text { German } \\
\text { shepher }\end{array}$ & $\begin{array}{l}\text { myoepithelial, tubular } \\
\text { epithelial cells }\end{array}$ & $16.1 \%$ & 7.5 \\
\hline phyllodes tumor & 1 & 3 years & Rot willer & $\begin{array}{l}\text { cellular stroma, gland } \\
\text { epithelial cells }\end{array}$ & $3.2 \%$ & 7.71 \\
\hline $\begin{array}{l}\text { Fibrocystic } \\
\text { disease }\end{array}$ & 1 & 3 years & pit ball & $\begin{array}{l}\text { fibrous stroma, } \\
\text { epithelial cells }\end{array}$ & $3.2 \%$ & --- \\
\hline
\end{tabular}

\section{4-Pathological examination:}

\section{A-Gross pathology:}

The mean diameter of nodules ranged from 5 to $15 \mathrm{~cm}$. Skin ulceration associated with the nodules in some cases. Most of mammary gland tumors were observed in the caudal pair of glands.

Tubulopapillary mammary carcinoma of Griffin 6 years dog (Photo. 2a) showed solid firm mass irregular shape which looked from gray to-whitish in color (Photo. 2b) cross section tumor revealed the lobular formation (Photo. 2c).

Phyllodes tumor of female Rot- willer age 3 years showing orange size overlaying the thicked skin at the level of the nipple (Photo. 3a) during mastectomy (Photo. 2b). Tumor was round in shape, firm in consistency (Photo 3c) cross section showed blackish greenish colure, lobular pattern delineated. (Photo. 3d).

Mixed mammary carcinoma of Griffin 10 years showed mass adjacent to the nipple was concealed by the dense hair coat overlying epidermal ulceration (Photo. 4a) Well-circumscribed large mass (Phot. $4 \mathrm{~b} \& \mathrm{c})$ in cut section showing the center of the neoplasm was hard in consistency with osseous texture (Photo.4d).

Complex Carcinoma of German shepherd 7years dog (Photo.5a). The tumour showed very hard rounded mass contain cleft-like space (Photo.5b). Tumor showing extensive hemorrhage inside the tumoure mass (Photo. 5c) multiple nodules invaded in the inguinal lymph node (Photo. 5d). 

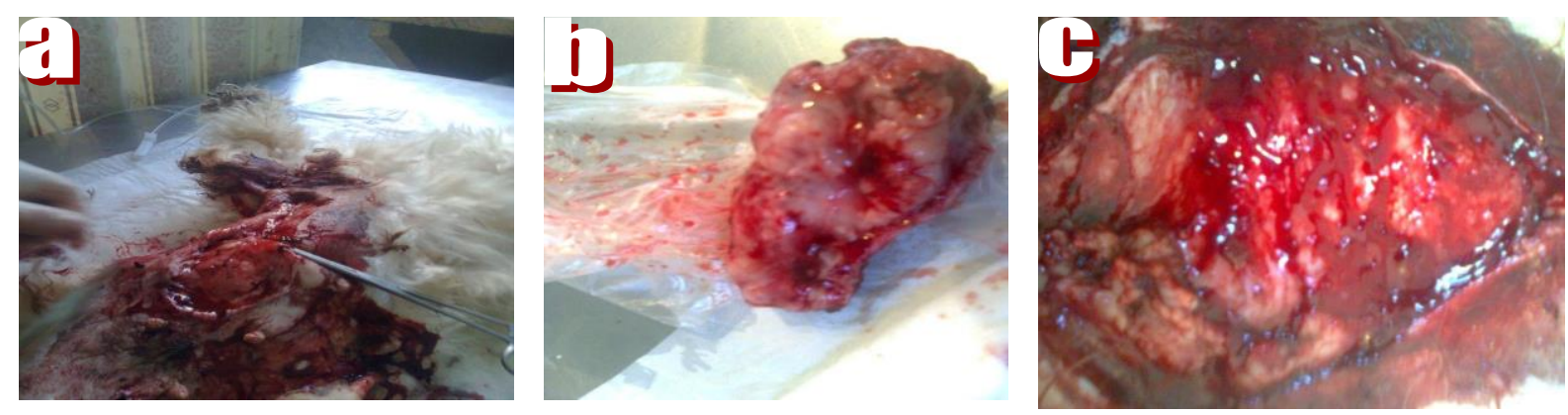

Photo 2: Tubulopapillary mammary carcinoma of Griffin 6 years dog (a) during mastectomy (b) Tumor showing solid firm mass irregular shape which looked from gray to-whitish in color.(c) Cross section of tumor revealing appearance of lobular formation.
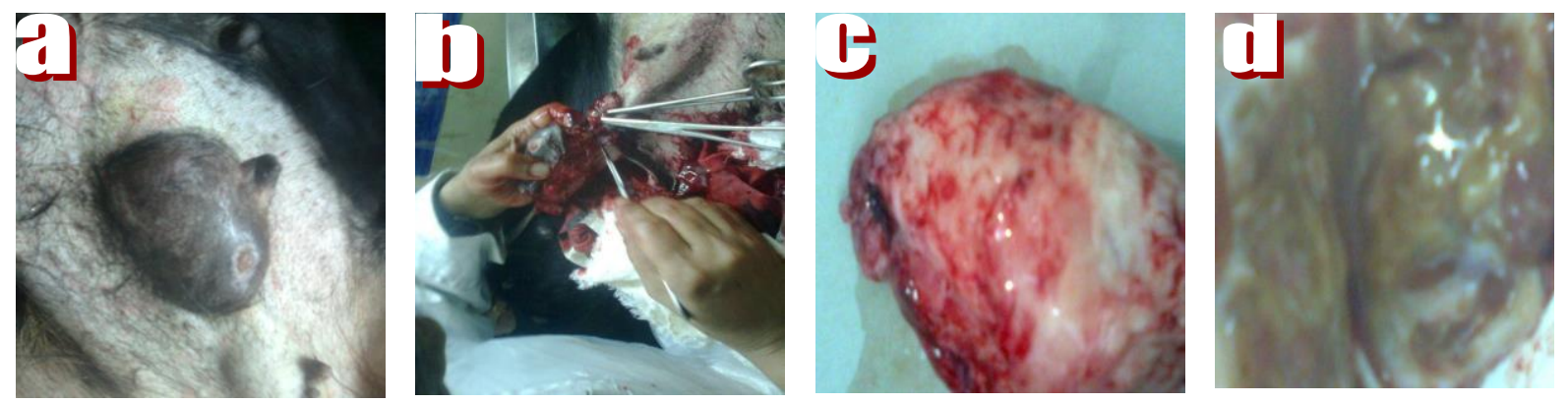

Photo 3: Phyllodes tumor of female Rot- willer age 3 years Showing (a) orange size overlaying the thicked skin at the level of the nipple (b) during mastectomy (b) Tumor was round in shape, firm in consistency (c) A cross section in Phyllodes tumor showed blackish greenish colure, lobular pattern delineated by fibrous septa.
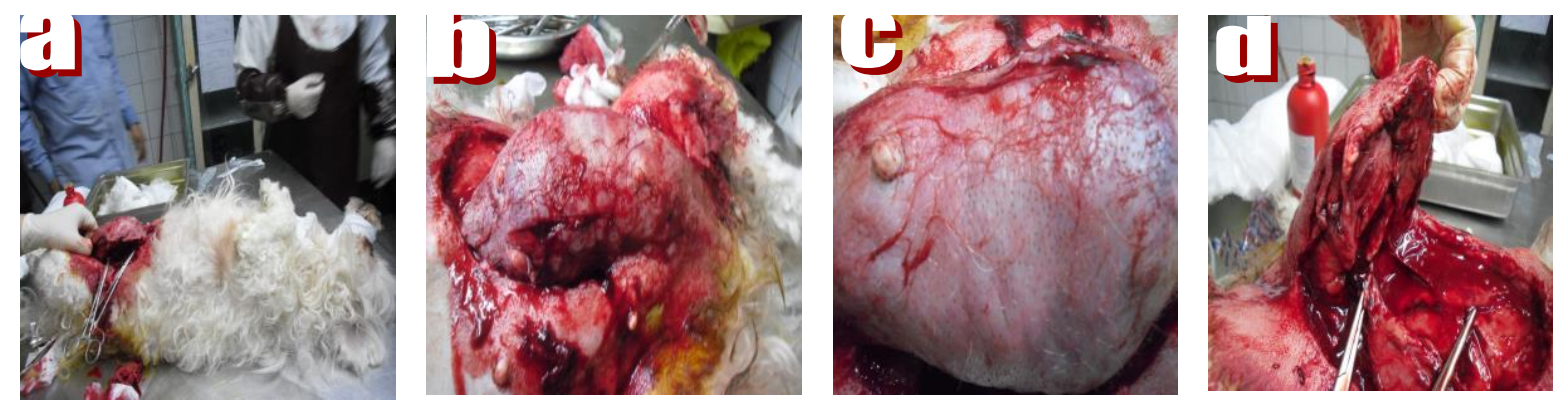

Photo 4: Mixed mammary carcinoma of Griffin 10 years showing (a) The mass adjacent to the nipple was concealed by the dense hair coat overlying epidermal ulceration (b\&c) Well-circumscribed large mass (d) in cut section showing the center of the neoplasm was hard in consistency with osseous texture.
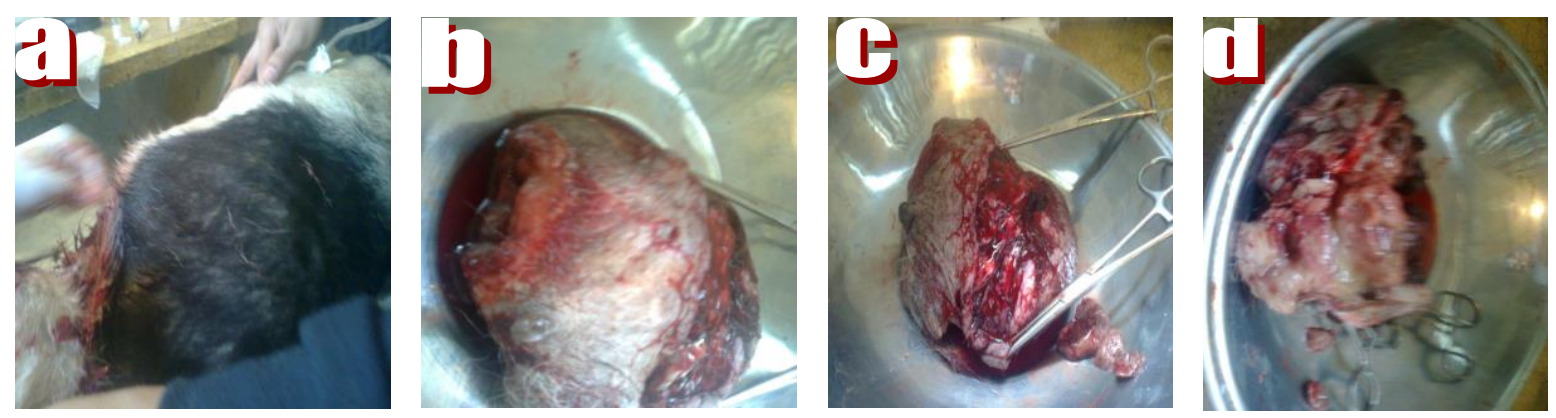

Photo 5: Complex Carcinoma of German shepherd 7 years dog (a) during mastectomy (b) the tumour showing very hard rounded mass contain cleft-like space (c) Tumor showing extensive hemorrhage inside the tumor mass (d) multiple nodules invaded in the inguinal lymph node. 


\section{B-Histopathological findings:}

1-Solid tubular carcinoma of 10 years griffin dog the mammary gland showed presence of abundant tubular structures separated by fibrous stroma (Fig.1a). The neoplastic cells infiltrated into the surrounding mammary tissue (Fig.1b). Cytoplasmic vacuolation, granular eosinophilic granules in cytoplasm. The tubules showed double layer cells. The cells were variable in shape, the nuclei were hypochromatic, normochromatic or hyperchromatic nucleoi were large single on small multiple (Fig. 1c). The intertubular stroma was infiltrated by plasma cells and lymphocytes (Fig.1d).

2- Tubulopapillary carcinoma of 6 years griffin dog mammary gland showed finger-like projections of ductal epithelial cells, the papillae were supported by fibrovascular connective tissue tumoure (Fig.2a). The tubulopapillary were extend into tubular lumina with clear center (Fig.2a). Neoplastic cells vary from columnar to polygonal with variable numbers of mitoses (Fig.2b). Tubulocarcinoma (Cribriform appearance), neoplastic epithelial cells forming a sieve like arrangement, Proliferation of a population of neoplastic epithelial cells forming a sieve like arrangement ,tumor cells surrounded by lymphocytic infiltration (Fig.2c). Moderate Nuclear and cellular pleomorphism (Fig.2d), mammary gland cells invaded through muscle bundle (Fig.2e). Dilated ducts filled by atypical cells necrosis within the center of the neoplastic cell (Fig.2f).

3-Anaplastic giant cell carcinoma of 8 years dog German shepherd mammary gland showed diffuse invasion of interlobular connective tissue by the undifferentiated neoplastic cells (Fig.3a), Invasive pleomorphic lobular mammary gland carcinoma cells with unusual shapes and variable sizes hyperchromatic pleomorphic nuclei (Fig. 3b) which may be accompanied by an infiltrate of lymphocytes (Fig. 3c). Neoplastic cells were individualized or grouped in small nests (Fig.3d). Cellular and nuclear atypia arranged predominantly in a haphazard fashion, Nuclei were rounded to oval, occasionally with coarsely chromatin (Fig. 3e). Multinucleated cells bizarre giant cells (Fig.3f).

4- Mucinous carcinoma of 9 years Rot willer dog mammary gland showed Malignant Myoepithelioma, oval to spindle shaped cells (Fig.4a), 'islands' of malignant cells with intracytoplasmic clear vacuoles and the cells had poorly demarcated cell borders (Fig.4b). Clusters of tumor cells floating in extracellular mucin lakes. (Fig.4c). Ducts showed hyperplastic wall with cystic formation, Proliferation of a multilayered stratified epithelial cells surrounded by cellular fibrous stroma (Fig.4d). Marked dilated cystic tubule supported by fibrovascular connective tissue, cystic lumina contain malignant cells (Fig.4e) criteria of malignancy such as a higher nuclear cytoplasmic ratio, nuclear and cellular polymorphism (Fig.f).

5-Mixed mammary carcinoma of 10 years griffin dog showed proliferated epithelial cells with loss of gland architecture (Fig.5a). The myoepithelial cells were running in various directions surrounded by glandular components (Fig. 5a). Lipid-rich carcinoma, the nuclei are at the periphery of the cell with a single large lipid vacuole within the cytoplasm (Fig.5b). Foci of cartilagenous metaplasia and chondroid matrix production were seen (Fig.5c). Islands of tumor osteoid were present within the neoplasm (Fig.5d). Greater cellularity and the significant pleomorphism and foamy macrophage (Fig.5e). Neoplastic cells have indistinct cell borders and oval to elongate hyperchromatic nuclei (Fig.5f).

6-Complex Adenocarcinoma of 7 years shepherd dog mammary glandm, the neoplasm characterized by presence of 2 cells populations.

A-Malignant (epithelioma and epithelium differentiation). Myoepithelioma showed spindled myoepithelial cells surrounded by a bloody collagenous matrix (Fig.6a). The population cells were arranged in irregular squamous differentiated tubules and nests supported by fibrous stroma. (Fig. 6b). Cuboidal to columnar cells epithelial cells showed pleomorphism with atypia, (Fig. 6c). The nuclei were hyperchromatic with increased nuclear: cytoplasmic ratio (Fig. 6d), Supra mammary lymph node showed degeneration (Fig.e) and inguinal lymph node were degenerated with marked hemorrhage (Fig. 6f).

B-Complex Adenofibroma was the second populations of cells showed lobular hyperplasia and proliferation of intralobular ducts and acini (Fig.7a) increased amount of interlobular fibrous connective tissue with hyaline granules. (Fig.7b). The tubules lined by cuboidal or columnar cells bilayered epithelium with round and uniform nuclei, considerable nuclear and cellular pleomorphism with atypia (Fig.7c). Myoepithelial cell proliferation surrounded by a basophilic mucinous matrix (Fig.7d). proliferation of periductal stromal cells (Fig. 7e) and cystic adenoid formation (Fig. 7f) Comedocarcinoma characterized by presence of centeral neoplastic cell aggregation and peripheral tissue showed aggregates of closely packed cells arranged in solid foci (Fig. $7 \mathrm{~g}$ ).

7- Phyllodes tumors of 3 years age Rot- willer mammary gland dog. The tumor composed of epithelial and stromal components. Epithelial part is made of slit-like double layered ducts, surrounded by hypercellular stroma. The tumor cells grow in a leaf like pattern (Fig.8a) cyst containing homogenous eosinophilic materials (Fig.8b). The stromal 
hypercellularity and overgrowth (Fig.8c). The border is usually invasive (Fig.8d), Mononuclear cellular infiltration through muscle bundles with atypia. cellural infiltration (Fig.8e).

8-Fibrocystic disease with duct ectatic changes of 4 years pit ball mammary gland dog showed benign growth formed of cystically diliated mammary duct. The cyst containing homogenous eosinophilic materials and foamy histocytes (Fig.9a). Typical ductal hyperplasia, the duct was obliterated by uniform cells. (Fig. 9b). Ducts lined by low cuboidal or hyperplal epithelium surrounded by myoepithelium cells (Fig.9b). The surrounding stroma is fibrotic admixed with adipose tissue (Fig.9c). Other morphologic variations include fibroadenoma-like picture (Fig.9d) and calcification (Fig.9e).

\section{Result of Immunohistochemical Staining:}

Benign Fibrocystic disease showed positive ER (Fig. 10a\&b) showed positive PR (Fig. 10c). Tubulopapillary carcinoma showed weak positive ER (Fig.11a) positive PR (Fig. 11b\&c). Anaplastic giant carcinoma showed negative ER (Fig.12a) positive PR (Fig.12b\&c). Mucinus carcinoma showed positive ER (Fig. 13a) negative PR (Fig. $13 \mathrm{~b} \& \mathrm{c})$. Complex carcinoma showed weak positive ER negative PR (Fig. 14a) and (Fig. 14b). Mixed Carcinoma showed negative PR (Fig.14c) and negative ER (Fig.14d).
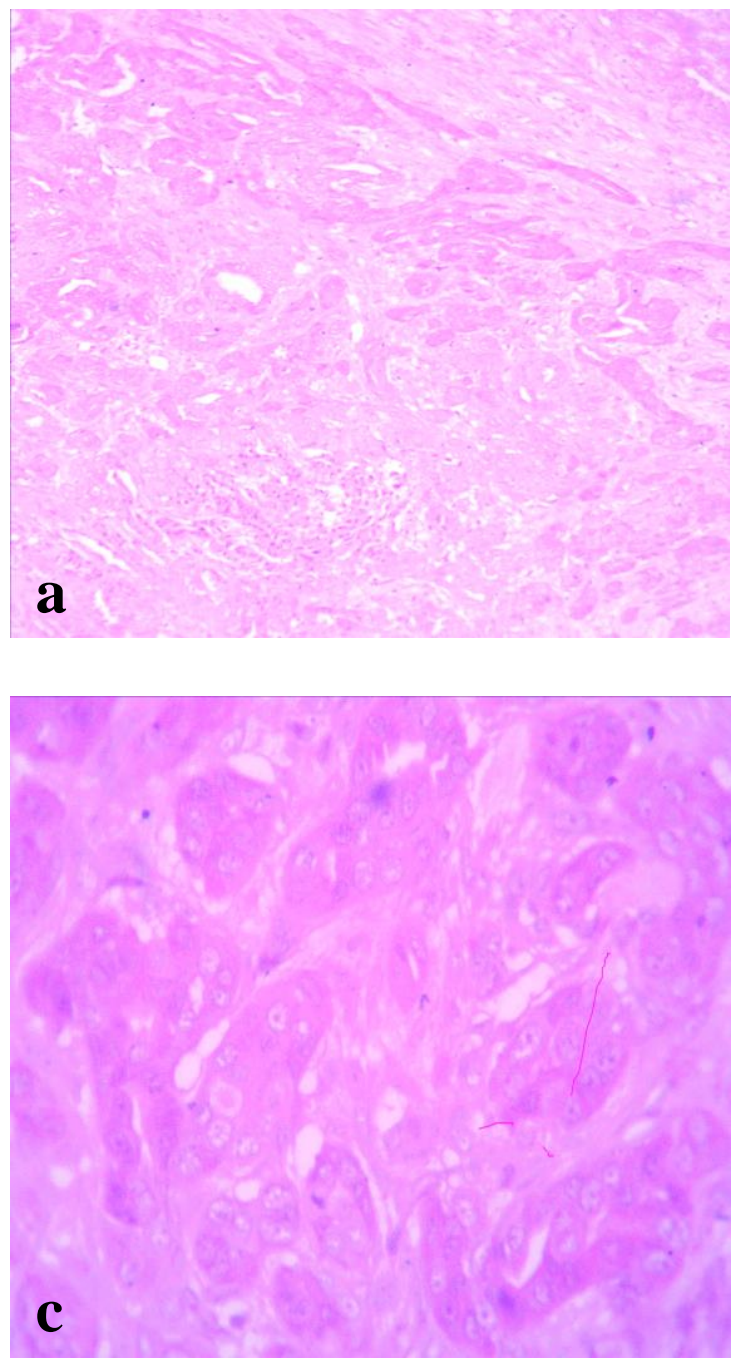
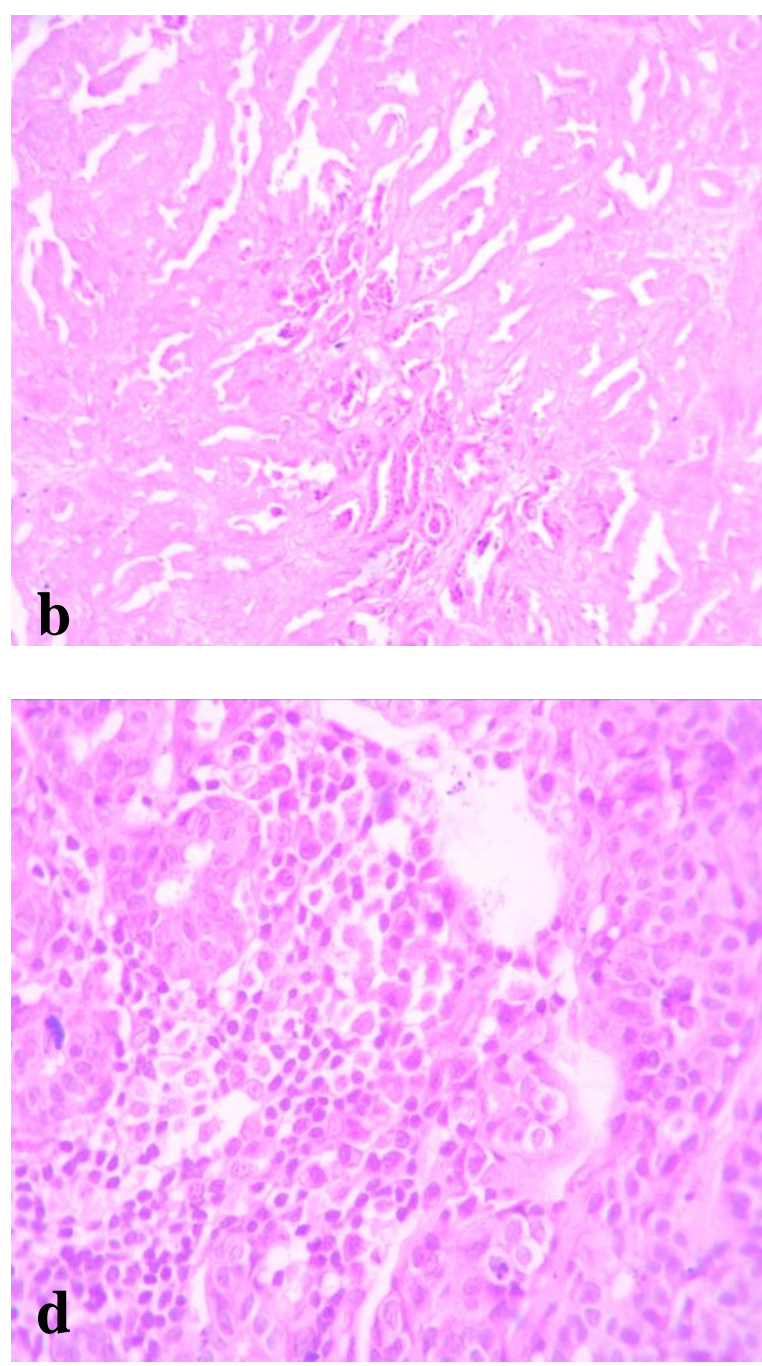

Fig.1 :(a) Solid tubular carcinoma of 10 years griffin dog mammary gland showing presence of abundant tubular structures separated by scanty fibrous stroma. H\&E X40.

Fig.1 :(b) Malignant cells scattered through Tubular adenocarcinoma. H\&E X100.

Fig.1 :(c) Cytoplasmic vacuolation, granular eosinophilic cytoplasm. H\&E X400.

Fig.1 :(d)Tumor cells surrounded by lymphocytic infiltration, presence of a squared off clear space between adjacent tumor cells. H\&E X400. 

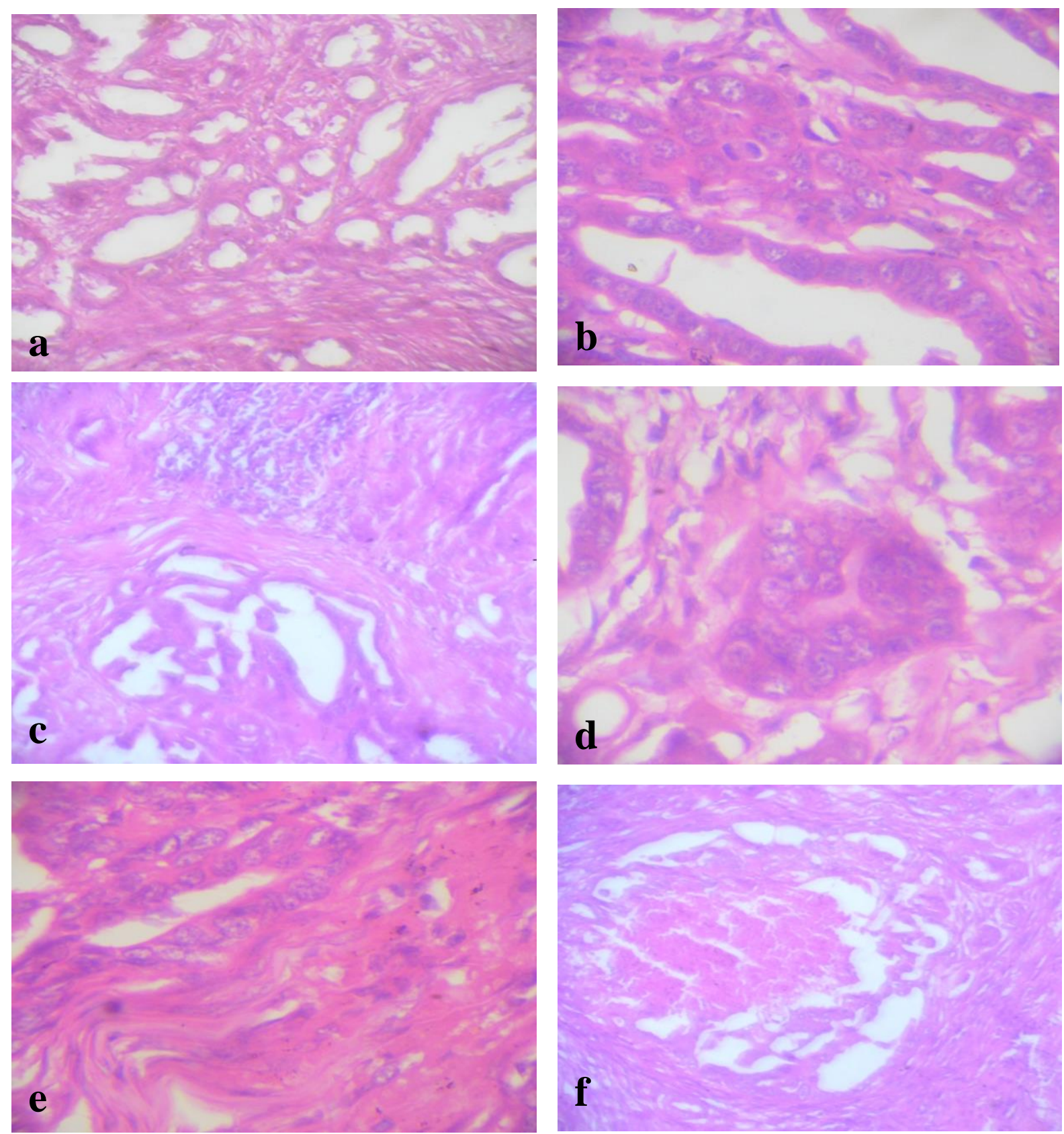

Fig.2 :(a)Tubulopapillary carcinoma of 6 years griffin dog mammary gland showing finger-like projections of ductal epithelial cells, The papillae are supported by fibrovascular stroma. H\&E X100.

Fig.2 :(b) tubule formations with clear lumen, mitotic figures. H\&E X400.

Fig.2 :(c) tubulocarcinoma (Cribriform appearance), neoplastic epithelial cells forming a sieve like arrangement, tumor cells surrounded by lymphocytic infiltration. H\&E X100.

Fig.2 :(d)) Nuclear and cellular pleomorphism of mammary gland .H\&E X400.

Fig.2 :(e) Mammary gland cells invaded in muscle bundles. H\&E X400

Fig.2 :(f) Dilated ducts filled by atypical cells with central necrosis. H \& E X100. 

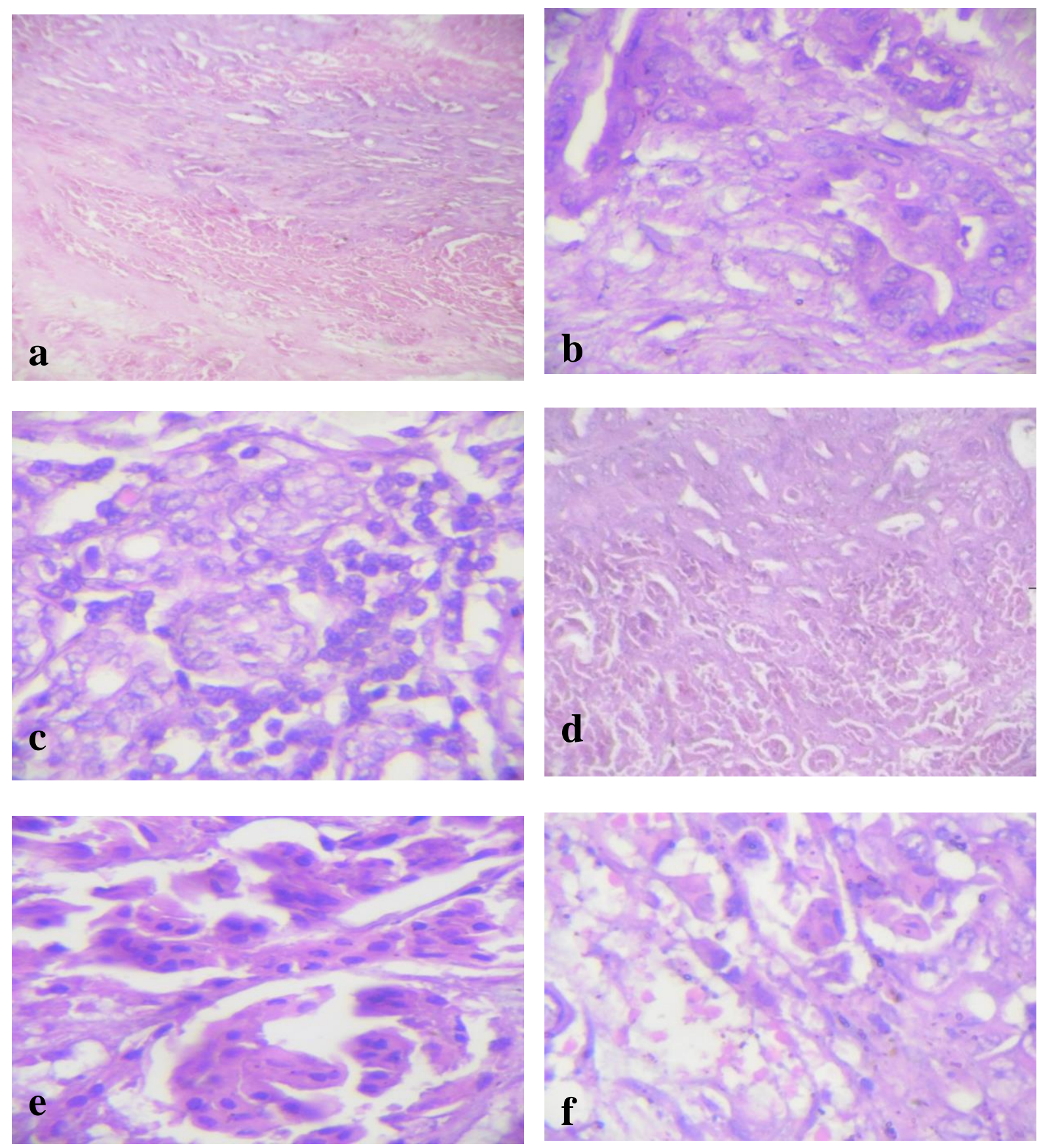

Fig.3 :(a) Anaplastic carcinoma of 8 years German shepherd dog mammary gland showing diffuse invasion of interlobular connective tissue. H\&E X40.

Fig.3 :(b) Invasive pleomorphic lobular mammary gland carcinoma cells with unusual shapes and variable sizes hyperchromatic pleomorphic nuclei. H\&E X400.

Fig.3 :(c) Tumor cells surrounded by lymphocytic infiltration. H\&E X400.

Fig.3 :(d) Neoplastic epithelial cells forming an atypical tubule grouped in small nests. H\&E X100.

Fig.3 :(e) Cellular and nuclear atypia arranged predominantly in a haphazard fashion. H\&E X400.

Fig 3 :(f) Multi-nucleated bizarre giant cells. H\&E X400. 

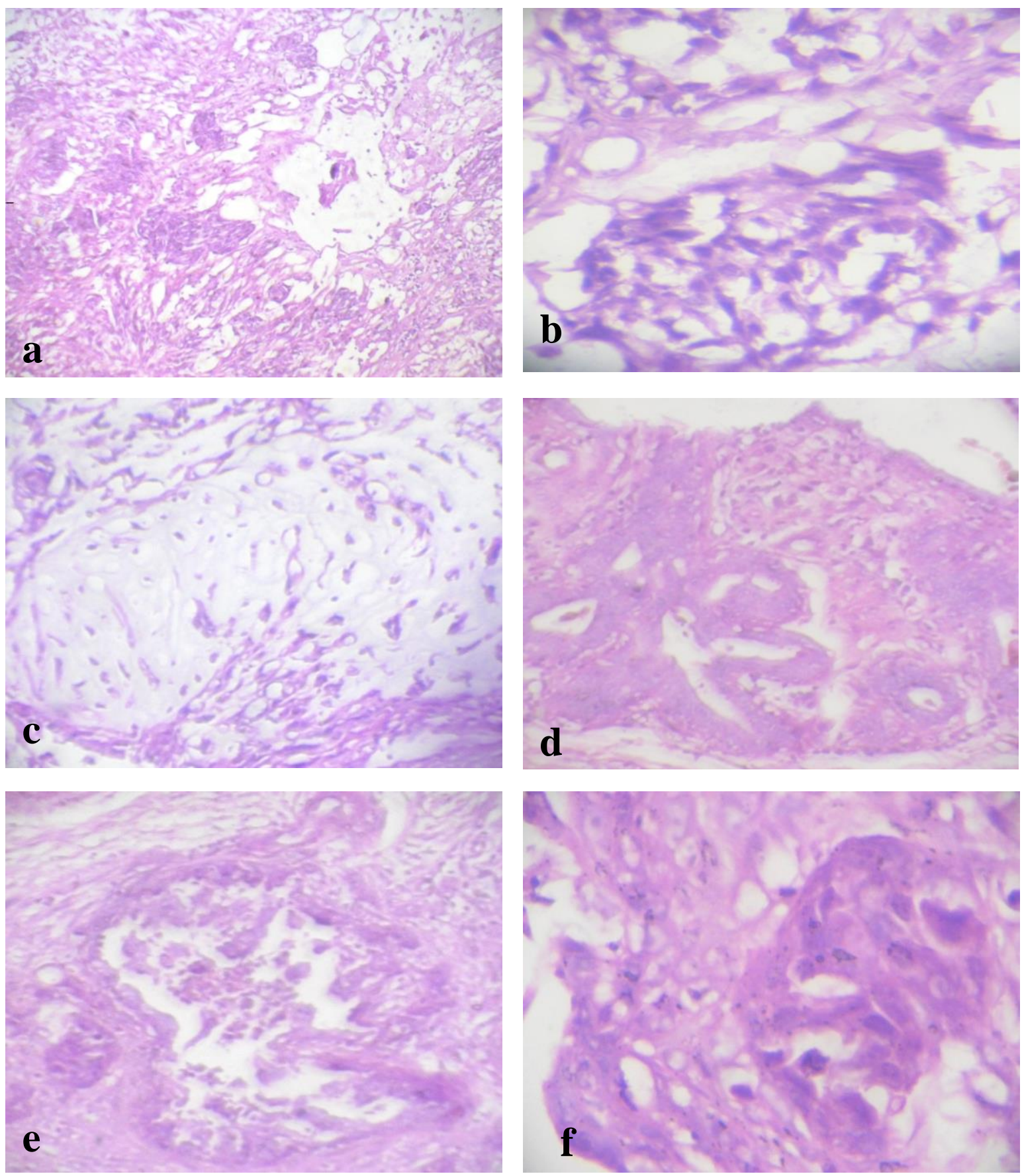

Fig.4 :(a) Mucinous carcinoma of 9 years Rot willer dog mammary gland showing Malignant Myoepithelioma, oval to spindle shaped cells. H\&E X100.

Fig. 4 :(b) 'islands' of malignant cells with intracytoplasmic clear vacuoles. H\&E X400.

Fig. 4 :(c) Clusters of tumor cells floating in extracellular mucin lakes. H\&E X100.

Fig. 4 :(d) Hyperplastic multilayered stratified population wall with cystic formation. H\&E X100.

Fig. 4 :(e) Dilated cystic tubule. The Lumina of cyst contain malignant cells. H\&E X100.

Fig. 4 :(f) Malignant criteria showing hyperchrmasia, nuclear and cellular pleomorphism. H\&E X400. 

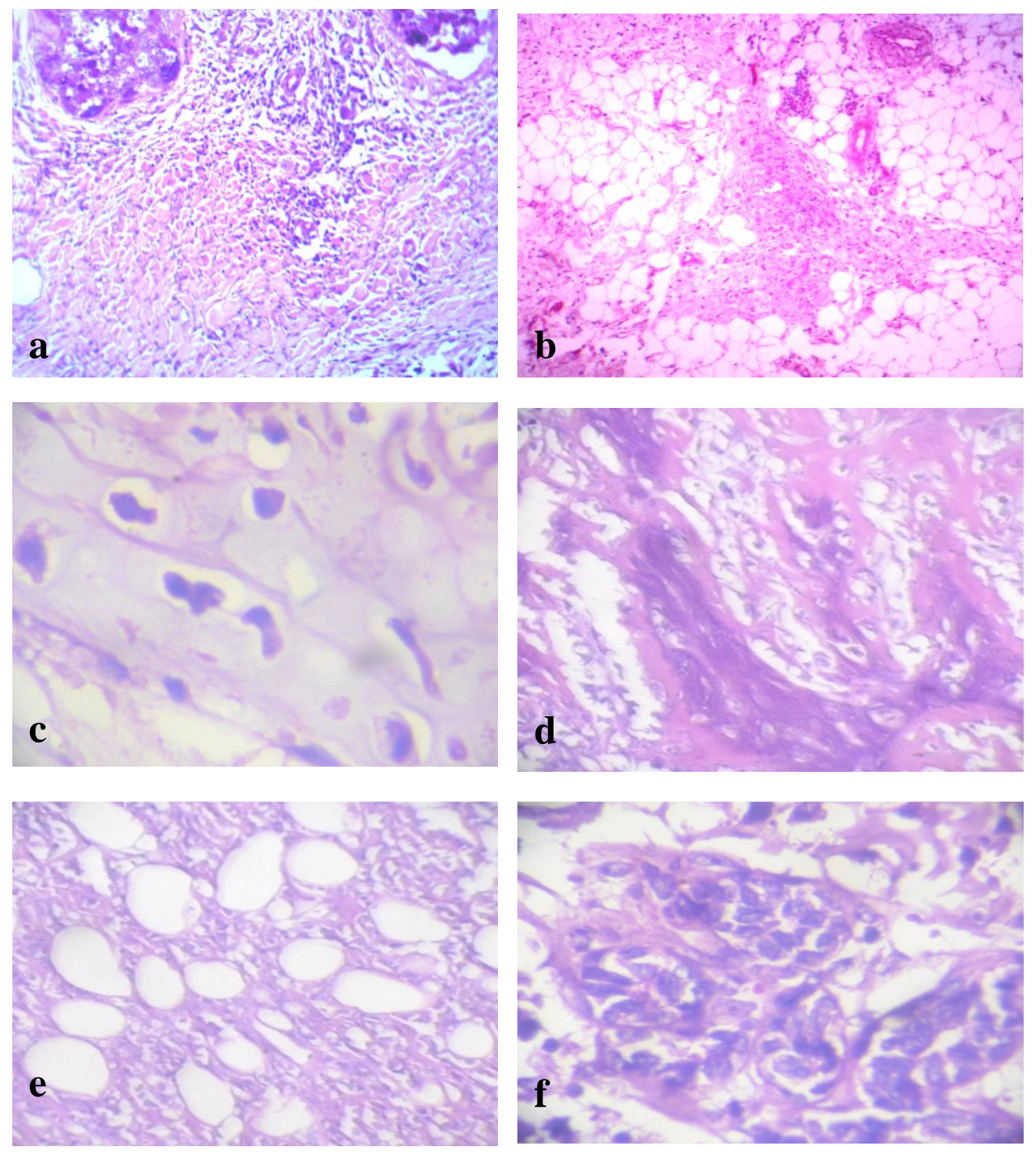

Fig. 5: (a) Malignant Mixed carcinoma of 10 years griffin dog mammary gland showing loss of gland architecture and spindled myoepithelial cells running in various directions. H\&E X 100 .

Fig. 5 :(b) Lipid-rich carcinoma, nuclei are at the periphery of the cell with a single large lipid vacuole within the cytoplasm. H \& E X100.

Fig. 5: (c) cartilagenous metaplasia and chondroid matrix production. H\&E X400.

Fig. 5: (d) Islands of tumor osteoid neoplasm. H\&E X100.

Fig. 5: (e) Pleomorphism of the myoepithelial cells and foamy macrophage. H\&E X100.

Fig.5: (f) The neoplastic populations cells have indistinct cell borders and oval to elongate hyperchromatic nuclei. H\&E X400. 

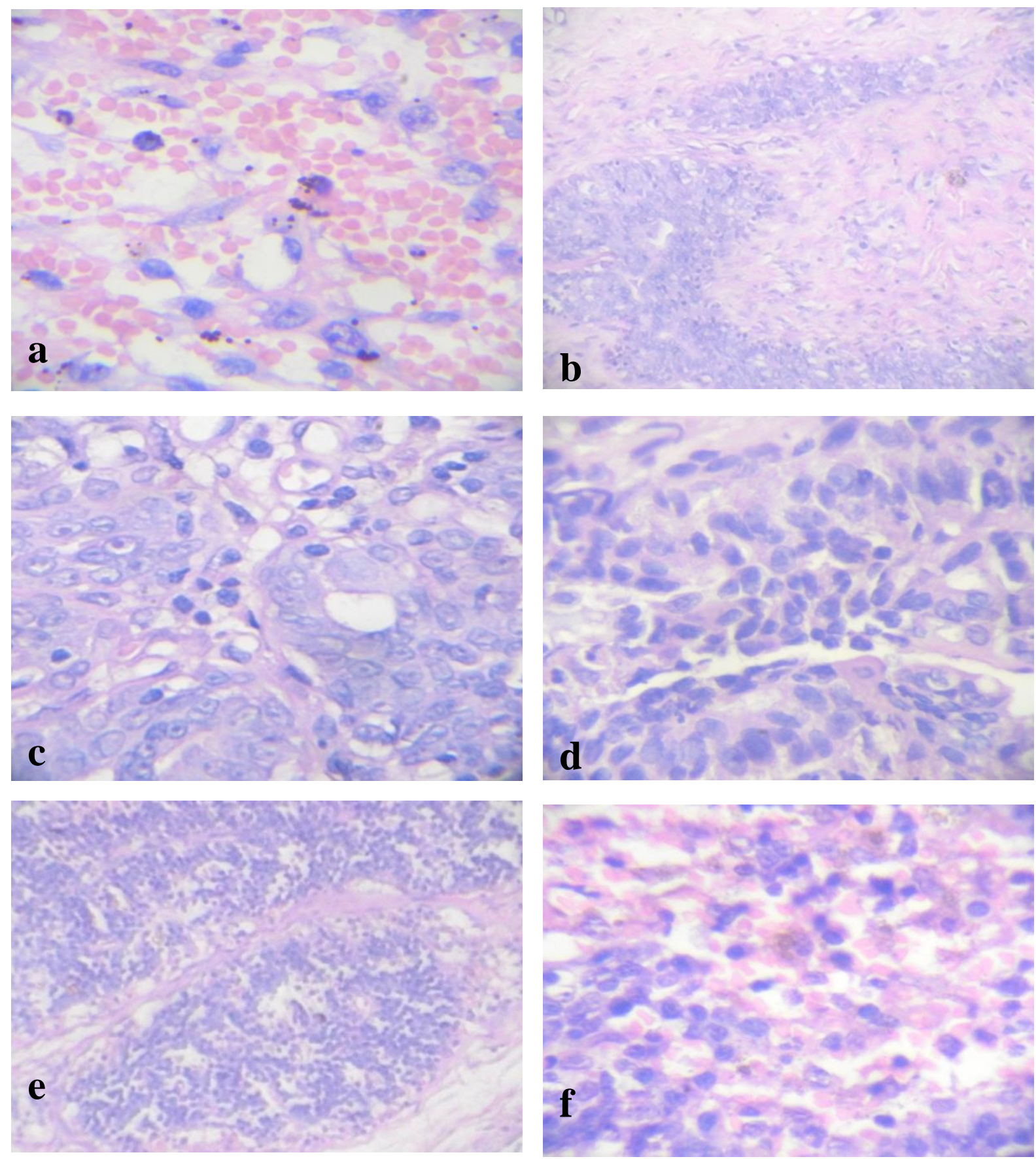

Fig.6 :(a) Malignant Myoepithelioma of 7 years German shepherd dog Mammary gland, showing spindled myoepithelial cells surrounded by a bloody collagenous matrix. H \& E X 400.

Fig. 6 :(b) Small groups of cells showing squamous differentiation and fibroma in central part. H \& E X100.

Fig. 6 :(c) The epithelial cells showing pleomorphism with atypia,. H \& E X400.

Fig. 6 :(d) Squamous differentiation. Epithelial cells pleomorphism with hyperchromatic nuclei. H \& E X400.

Fig. 6 :(e) Supra mammary lymph node showing degenerative changes. H \& E X100.

Fig. 6 :(f) Inguinal lymph node showing degeneration with hemorrhages. H \& E 400. 

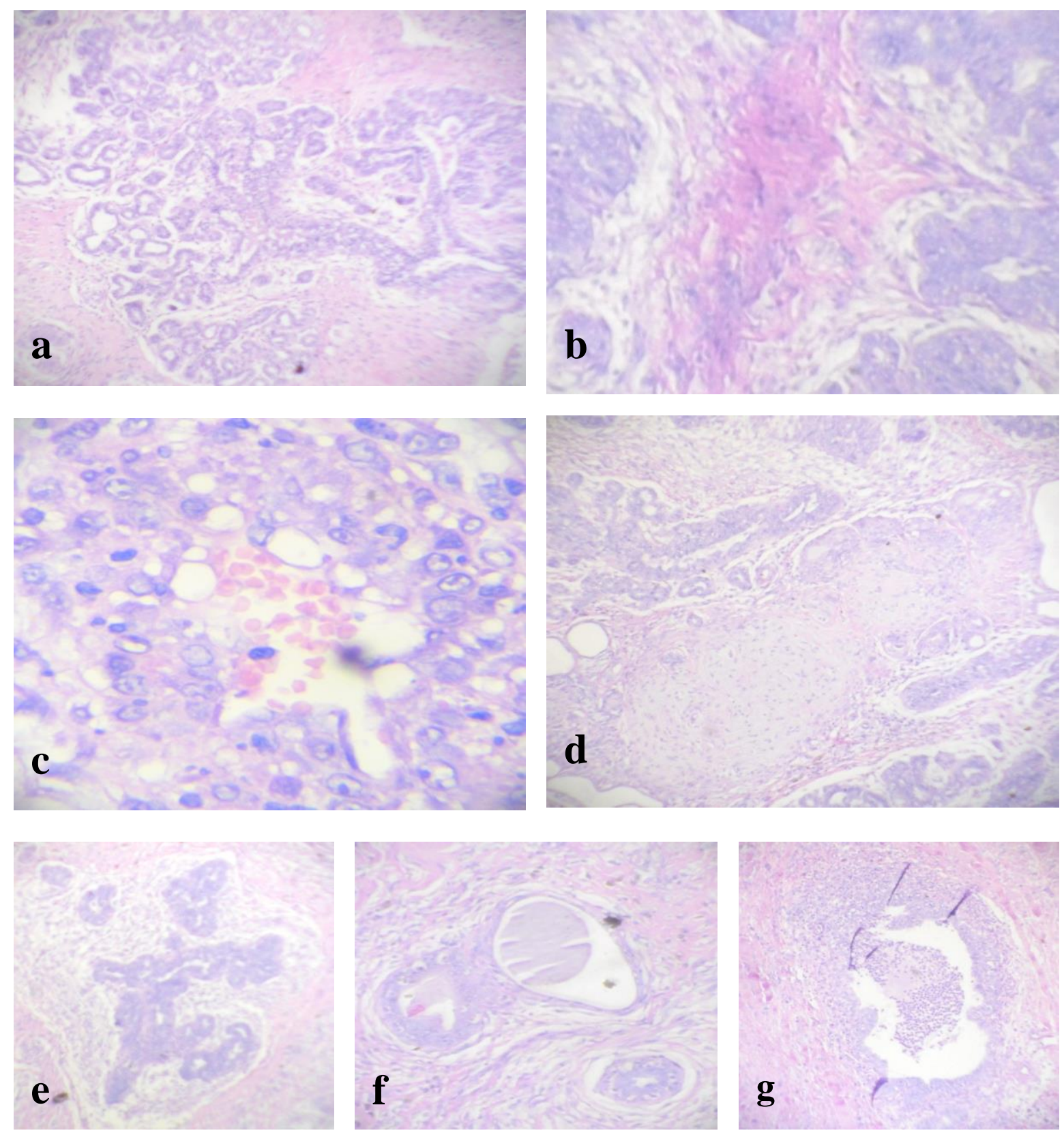

Fig.7: (a) Mammary gland of 7 years German shepherd dog showing complex adenofibroma, lobular hyperplasia with intralobular fibrosis. H\&E X40.

Fig.7: (b) Lobular hyperplasia with hyaline granules .H\&E X100.

Fig.7: (c) The tubule are lined by a bilayered epithelium considerable nuclear and cellular pleomorphism with atypia. H\&E X400.

Fig.7: (d) myoepithelial cell surrounded by a basophilic mucinous matrix. H\&E X40.

Fig.7: (e) Fibroadenomatous change showing proliferation of the interlobular ducts. H \& E X100.

Fig.7: (f) Cystic adenoid. H\&E X100.

Fig.7: (g) Comedocarcinoma showing dilated ducts filled by atypical cells. H \& E X100. 

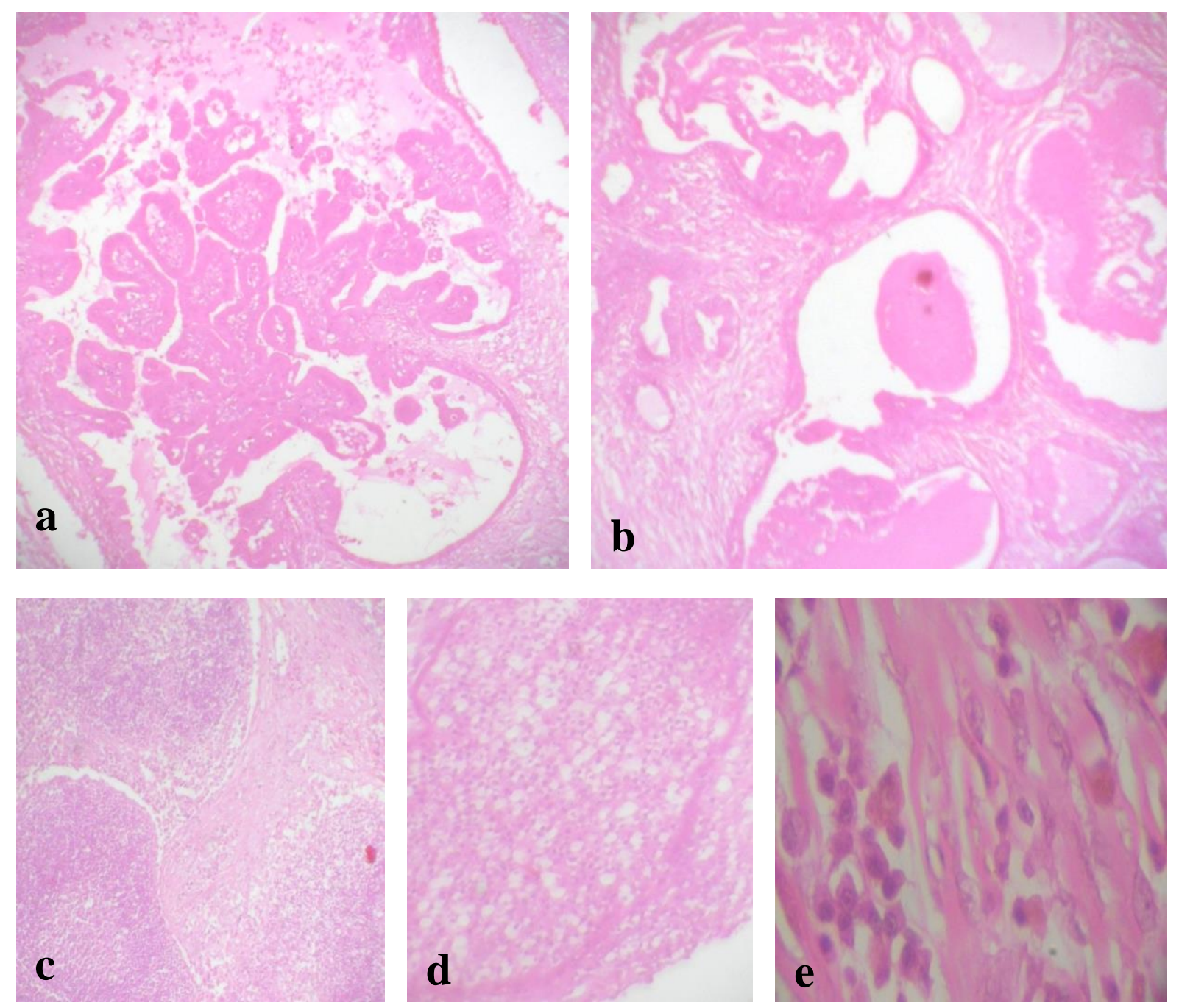

Fig.8:(a) phyllodes tumor of 3 years Rot- willer dog Mammary gland showing 'leaf-like' architecture lined by cuboidal epithelium. H\&E X40.

Fig.8:(b) Cystically dilated duct containing homogenous eosinophilic materials surrounded by myoepithelium cells. H\&E X40.

Fig.8:(c) Lobular hyperplasia with fibrosis H\&E X100.

Fig.8:(d) Stromal hypercellularity surrounding the slit-like epithelial component. H\&E X400.

Fig.8:(e) Mononuclear cellular infiltration through muscle bundles with atypia. H \& E X1000. 

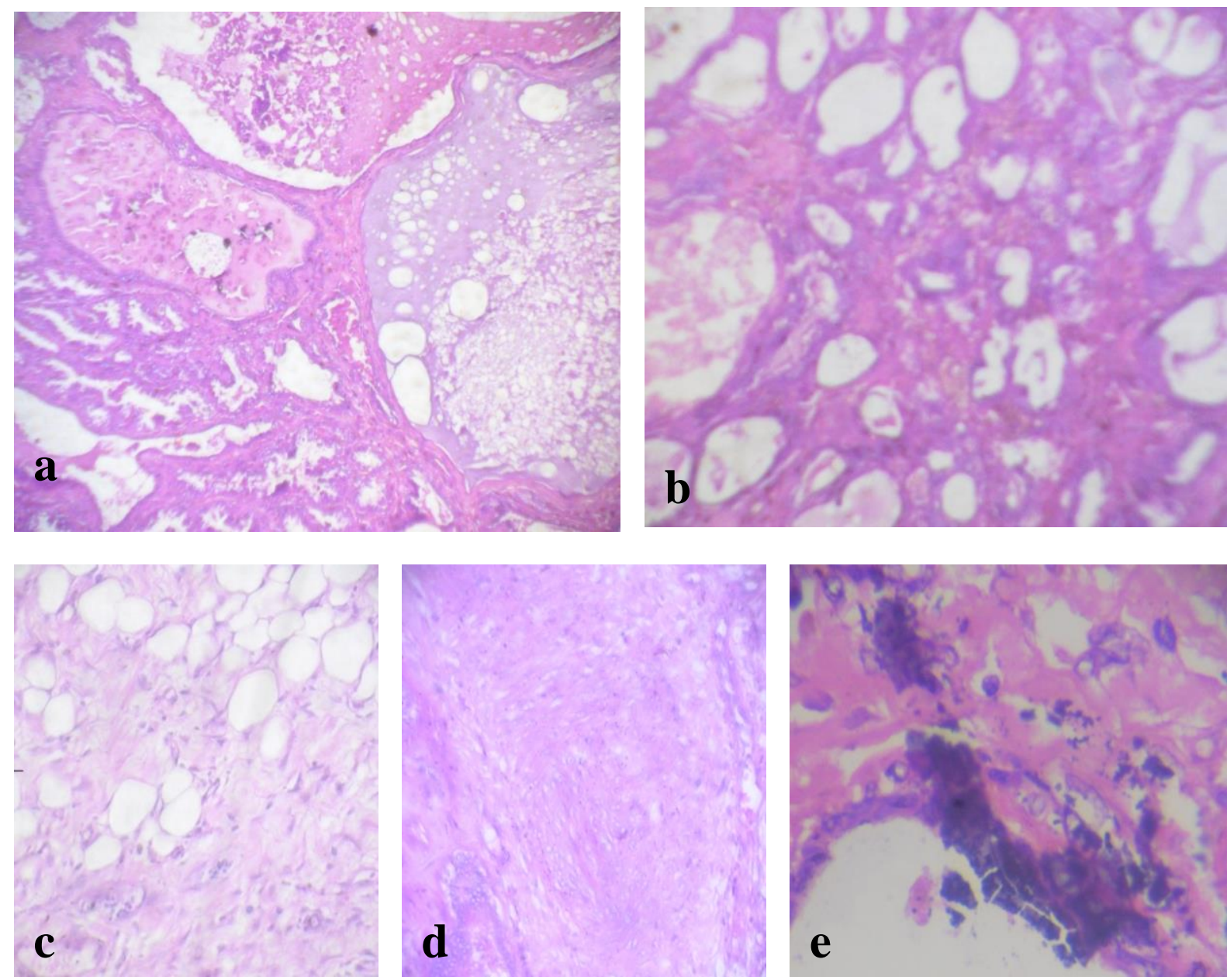

Fig.9:(a) Fibrocystic disease with duct ectatic changes of 4 years pitball dog mammary gland showing dilated cyst cyst containing homogenous eosinophilic materials and foamy histocytes. H\&E X100.

Fig.9:(b) typical ductal hyperplasia, the duct is obliterated by uniform cells lined by low cuboidal epithelium. $\mathrm{H} \& \mathrm{E} X 400$.

Fig. 9 :(c)The stroma showing fibrosis admixed with adipose tissue. H\&E X400.

Fig. 9:(d): Fibrocystic disease showing fibroadenoma-like picture. H\&E X400.

Fig. 9:(e): Fibrocystic disease showing calcification. H\&E X100.
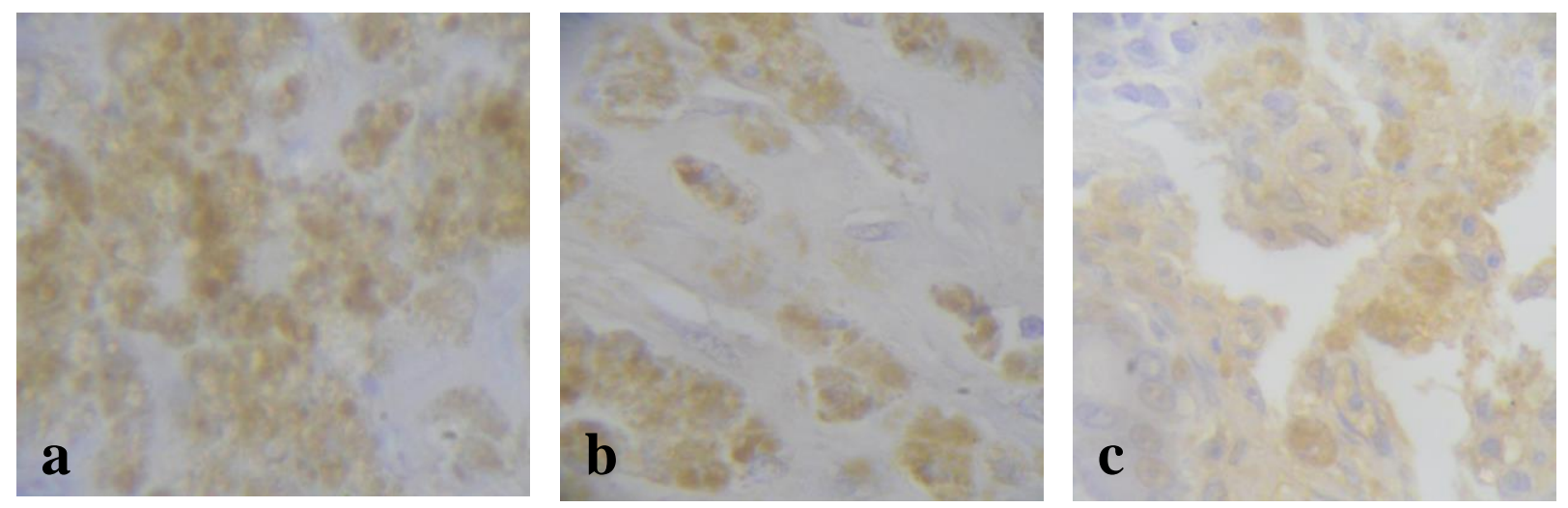

Fig.10: Immunohistochemical Staining of benign Fibrocystic disease showing (a\&b) positive for (ER).

(c) Fibrocystic disease showing positive for (PR). Counterstaining: Harris's hematoxylin. X400. 

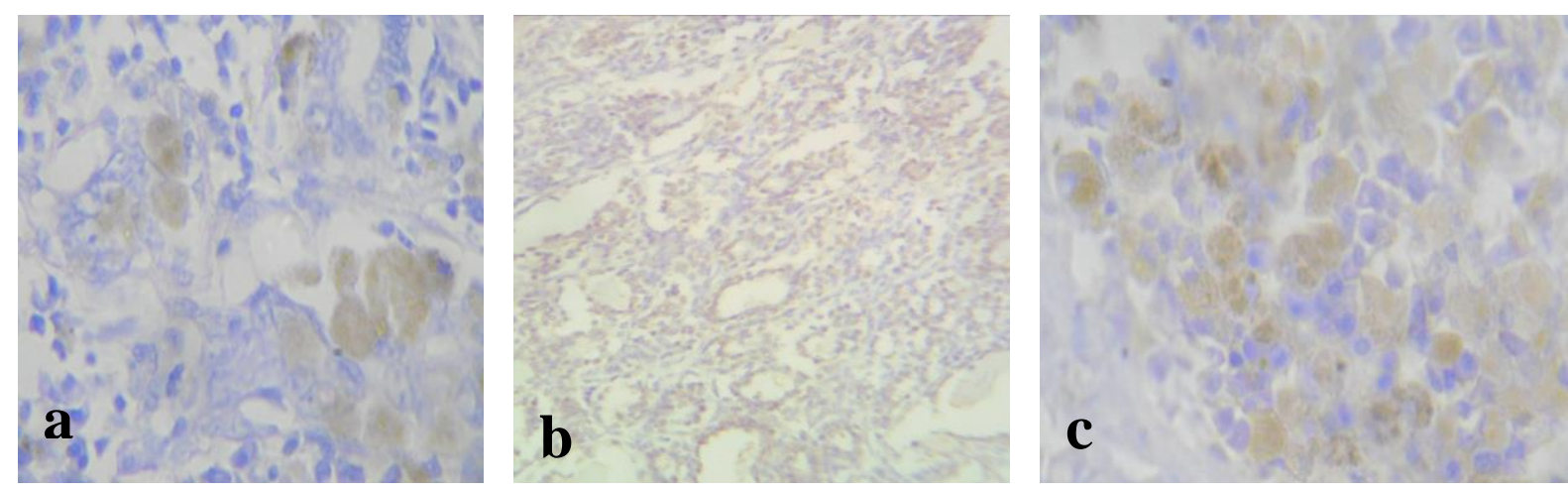

Fig.11: (aX400) Immunohistochemical staining tubuloPapillary mammary carcinoma showing weak positive for (ER).

(bX100\&cX400) tubuloPapillary carcinoma showing positive for (PR). Counterstaining:Harris's Hematoxylin.
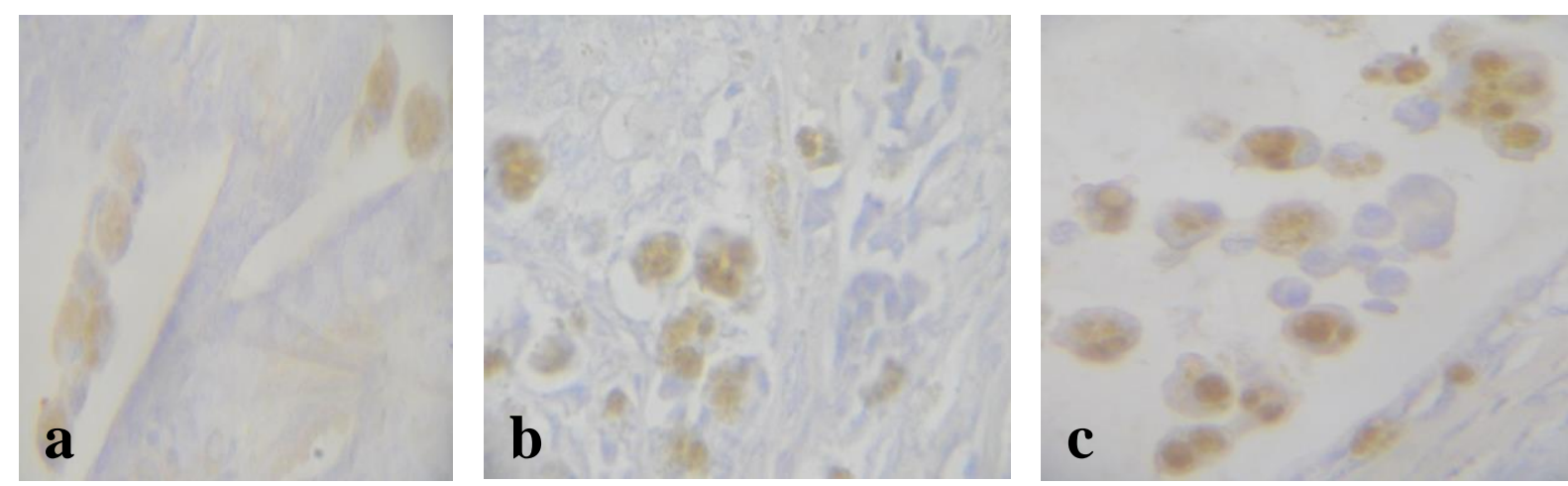

Fig. 12: (a). Immunohistochemical staining of anaplastic giant carcinoma showing negative for (ER).

(b\&c) anaplastic giant carcinoma showing positive for (PR). Counterstaining: Harris's hematoxylin. X400.
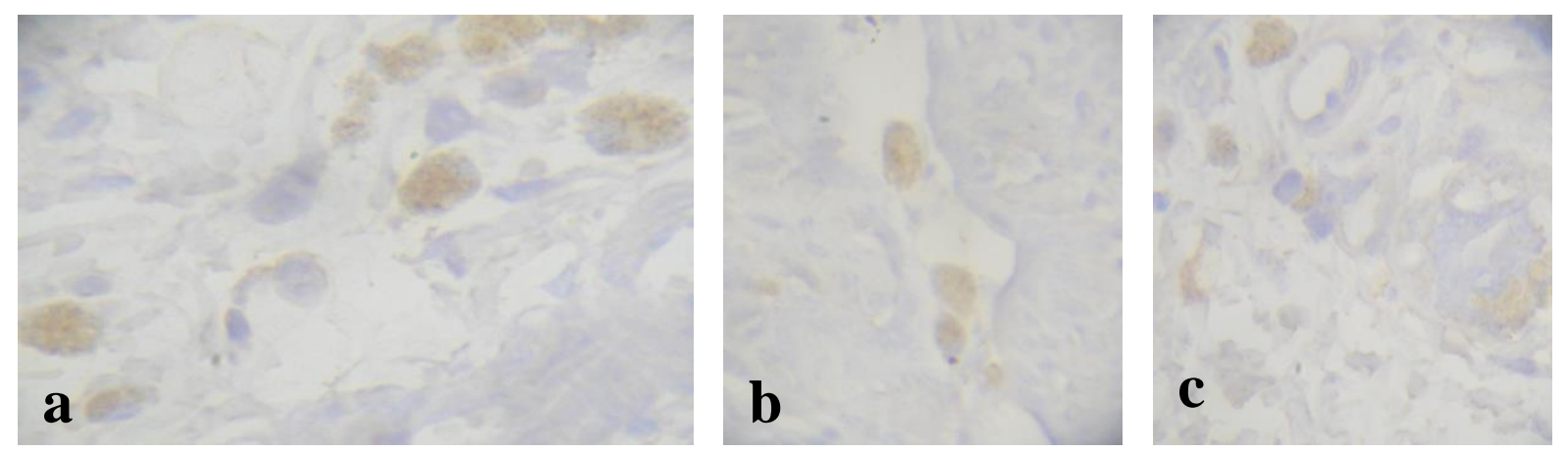

Fig. 13: Immunohistochemical staining of mucinous carcinoma showing (a) positive for (ER). (b \&c) mucinous carcinoma showing negative for (PR). Counterstaining staining: Harris's hematoxylin. X400.
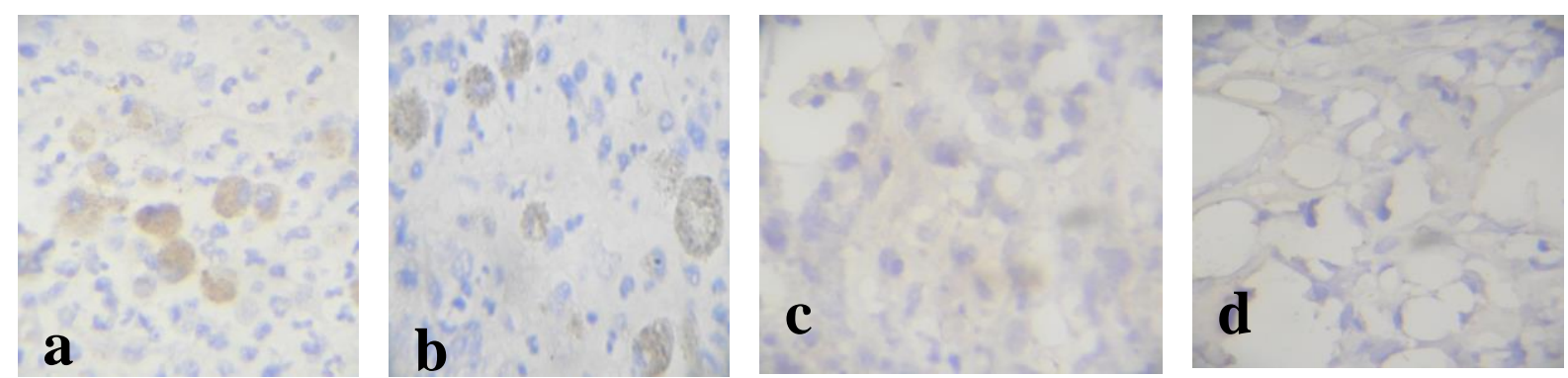

Fig.14: Immunohistochemical staining of complex carcinoma showing (a) weak positive for (ER).

(b) Complex carcinoma showing negative for (PR).

(c) Mixed Carcinoma negative for (ER). (d) mixed Carcinoma negative for (PR). Counterstaining: Harris's hematoxylin. X400. 


\section{DISCUSSION}

In the present study, the blood samples were collected from dogs came to the veterinary clinics either for routine chick up or suffering from disease conditions. The main obstacle in performing this study was refusal of the owners to perform surgery or to collect blood. Another difficulty was the arrival of the affected cases in advanced stage of tumor development.

The results of CA15-3 tumor marker revealed that the normal serum value of CA 15-3 in non tumor bearing dogs is $\geq 1 \mathrm{U} / \mathrm{L}$ regardless of the animal breed and or age. This is in partial agreement with Ledecky et al. (2013) as they reported that neither the weight nor age of the animals had an influence on the measured physiological values of CA 15-3. The previously reported normal physiologic values for CA15-3 in dogs seemed to be contradictory. $0.5 \mathrm{u} / \mathrm{ml}$ and $3-7 \mathrm{u}$ $/ \mathrm{ml}$ were previously reported by Manuali et al. (2012) and Ledecky et al. (2013). High values 30-35 u /ml were reported in human. This apparent contradiction and irrelevant of the results were related to the differences in the laboratory methods adopted for measuring as well as serum or plasma was used (Bablok et al.,1988).

In the present study, the serum levels of CA 15-3 were increased in tumor bearing dogs $(7.1 \sim 7.7 \mathrm{U} / \mathrm{ml})$ in comparison to normal non tumor bearing dogs regardless of the breed or age. These findings are in harmony with the results of previous reports. Early Duffy, (2006) pointed out that CA 15-3 concentration of a 5 - to 10-fold above the upper limit of the reference interval should alert the physician to the presence of metastatic disease. Manuali et al. (2012), reported CA $15-3$ values of $0.64,1.21$ and $1.33 \mathrm{U} / \mathrm{ml}$ in tumor bearing dogs, and they correlated the results to the stage of malignancy. No relation between Tumor size, skin ulceration, necrosis, inflammation and histological type of tumor and serum levels of CA 15-3 was observed. Moreover Campos et al. (2012) concluded that Serum CA 15.3 can be used to distinguish nonmetastatic from metastatic carcinomas. Da Costa, (2012) said most of the markers applied for detection of human CTCs circulating tumor cell (CTCs) failed to detect canine CTCs.

The results also figured out increase in serum level of CA $15-3(17 \mathrm{u} / \mathrm{ml})$ in non tumor bearing dogs suffering from variable disease conditions in comparison to either healthy or tumor bearing dogs. Similar increase in the serum level of CA15-3 were previously reported in patients with certain benign diseases, especially liver disease; and in patients with other types of advanced adenocarcinomas (Duffy, 2006).
The results indicates that increase in serum values of CA $15-3$ is partially related to the degree of tissue damage which explain the increased serum level in malignant and metastatic mammary carcinoma.

The differences in the numerical values of serum level of this mammary tumor marker, CA 15-3 in the present study and the previously reported are strongly attributed to the differences in the methods used in testing. Moreover, this method-dependant differences are the cause of numerous medical interpretations of the test values.

The results of hematological examination in the present study revealed the presence of microcytic hypochromic anemia, which could by attributed to chronic ulceration and skin abrasions of the neoplasm. Similar findings and explanation were previously reported Hoffbrand et al. (2005) said that anemia is the most frequent haematological abnormality in cancer patients and may be due to many causes as a result of hemorrhage accompanied with tumors or metastatic of the tumor to bone marrow which lead to hematological abnormalities. Anemia of chronic disorders will affect almost all cancer patients at some stage of their illness. Although cancer-related hematologic abnormalities are frequently described in the veterinary literature, the incidence, prevalence, and clinical significance of these abnormalities are less well-defined (Childress, 2012).

Kruth and Carter, (1990) reported that extramarrow malignancies cause blood abnormalities, but the potential for normal marrow function is present. The leukocytosis, especially neutrophilia detected in most cases of tumor bearing dogs that sometimes reached to $30.000 / \mu 1$ could be attributed to the direct effect of neoplastic tissues through production of granulocyte macrophage colony stimulating factor (G-CSF) or a similar substance that stimulates neutropoiesis, or indirectly through stress induced neutrophilia (Stockham and Scott, 2002). Moreover, Itoh et al. (2009) attributed the increase of neutrophils, acidophils and monocytes in tumor-bearing dogs to inflammatory reaction at sites of tumor development and infection resulting from decreased immunity.

The distribution of mammary lesions according to breed and age of female dogs in Egypt has not yet been established. The most common breeds affected were, griffin, Rot -weiller and German shepherds at the range of 3 - 10 years of age. This interval of risk age is in agreement with other studies (Nieto et al., 2000; Yang et al., 2006; Hsu et al., 2009). An interesting finding was the high percentage of malignant mammary tumors revealed 95\% (30\%) malignant and 5\% (1\%) benign tumors. Some studies showed that half of the surgically removed mammary tumors in bitches were malignant Peña et al. (2003) 
and Kurilj et al. (2011). In spite of the high percentage of malignant mammary tumors (according to WHO classification), the vast majority of malignant tumors were well differentiated adenocarcinomas, mostly mixed complex and tubulopapillary which were similar to other studies (Millanta et al., 2006; Yang et al., 2006; Thuroczy et al., 2007; Hsu et al., 2009).

The histological results in this study revealed several types of carcinomas solid tubular, tubular papillary carcinoma, invasive, pleomorphic carcinoma, mucinus adenocarcinoma, mixed carcinoma, complex adenfibroma with carcinoma and malignant myoepithelioma and phyloyds. These were the prominent type of mammary gland malignant tumor of dog. Fibrocystic disease was the benign tumor in mammary gland of dog.

In tubulopapillary carcinoma which the neoplastic tubules were predominantly arranged in a sessile or pedunculated papillary fashion, solid carcinoma was one in which the cells are predominantly arranged in solid sheets, cords, or masses, without lumina (Misdorpet et al., 1972 and Misdorpet et al., 1973). Myoepithelial cells are consistently absent (Collins and Schnitt, 2008; Rosen, 2009 and Rosai and Ackerman's, 2011). In this result the tubulopappilary carcinoma was accompanied with cribriform and comedocarcinoma.

The origin of anaplastic giant cell carcinoma within the mammary tissue was often difficult to find because no neoplastic nodules could be identified within the tissue submitted for histopathology (Goldschmidt et al., 2011). Neoplastic cells were often individualized or grouped in small nests. Nuclei were round to oval, occasionally indented or convoluted with coarsely stippled chromatin. Multiple variably sized nucleoli are frequently present (usually, 2 or 3). Multinucleated cells were containing several irregularly sized nuclei (Goldschmidt et al., 2011). Similar results were obtained in this work.

Mucinous carcinoma known as colloid carcinoma was a form of invasive ductal carcinoma, in which clusters of tumor cells floating in extracellular mucin lakes. Grossly, the tumor was well circumscribed with a gelatinous cut surface (Rosen, 2009; Rosai and Ackerman's, 2011). Besite mucinus carcinoma, malignant myoepithelioma and cystic papillary adenocarcinoma were demonstreated in this result.

The malignant mixed mammary tumor was composed partly of cells morphologically resembling the epithelial component and partly of cells morphologically resembling connective tissue elements, both types of which were malignant (Misdorp et al. (1972); Misdorp et al., 1973). It was an uncommon mammary gland neoplasm, but it most often presents as a carcinoma and osteosarcoma. The epithelial component metastasizes via lymphatic vessels to regional lymph nodes and the lung via the hematogenous route to the lungs (Goldschmidt et al., 2011). Mixed carcinoma was the most frequent mammary tumor in bitches. The most frequently affected glands in our study were the inguinal glands. This was in agreement with previous reports (Patsikas 2006, Pereira 2003).

Goldschmidt et al. (2011) stated that carcinoma and malignant myoepithelioma, both the epithelial and the myoepithelial components were malignant. This malignant neoplasm was characterized by the presence of two cell populations supported by moderate fibrous stroma. This result agreed with the previous studies but there was complicated with fibroadeno complex. Adenosquamous carcinoma was composed of areas of carcinoma of any type admixed with foci where the neoplastic cells exhibited squamous differentiation and features of malignancy (Pulley, 1973). The presence of myoepithelial cells in complex carcinomas was associated with less aggressive biological behavior and a better prognosis than with simple carcinomas (Misdorp et al., 1999; Misdorp et al., 2002). In canine mammary neoplasm, tumor type was an important factor. An increasing range was observed in malignancy of complex carcinoma (composed of both epithelial and myoepithelial components) to simple carcinoma (composed of the one type of cell either epithelial or myoepithelial like cells) to sarcoma Misdorp et al. (1999). Comedocarcinoma was characterized by solid growth of pleomorphic cells within the ducts with area of central necrosis and dystrophic calcification. Some comedocarcinoma were present with a palpable mass (Pinder, 2010; Rosen, 2009; Rosai and Ackerman's, 2011).

Phyllodes tumor Phyllode tumors were a fibroepithelial tumor composed of epithelial and cellular stroma components. They were considered as benign, borderline, or malignant depending on histological features including stroma cellularity, infiltration at the tumor's edge and mitotic activity. All forms of phyllodes tumors were regarded as having malignant potential. These tumors were very fast growing and can increase in size in just a few weeks (Guillot et al., 2011). Peyman et al. (2013) described phyllodes tumor as a rare mammary gland tumor. Grossly, the mass was rigid, firm and immobile. On cut surface, it was solid and gray-white and showed cleft-like spaces.

Fibrocystic disease was one of the most common benign breast lesions. Histologically it was characterized by overgrowth of both fibrous stroma, and epithelial elements, ducts and lobules, in differing proportions. The basic morphologic changes in the 
fibrocystic disease were cysts formation, apocrine metaplasia and fibrosis (Guray and Sahin, 2006; Batemam, 2006; Rosen, 2009; Rosai and Ackerman's, 2011). The cyst lining may be flattened, or shows apocrine metaplasia and epithelial hyperplasia (Rosai, 2011; Batemam, 2006). Apocrine metaplasia was characterized by abundant granular eosinophilic cytoplasm with apical snouts (Rosai; 2011). Stromal fibrosis was also a common finding. Epithelial hyperplasia whether typical or atypical may be occurred (Hartman et al., 2005; Guray 2006).

In the present study, we combined histopathology with immunohistochemical staining of estrogen receptors (ER) and progesterone receptors (PR) in canine mammary gland tumors. The cells of the mammary gland contain estrogen and progesterone receptor protein a member of family of nuclear receptors which enhance transcriptional activity of selected genes (Leong et al., 2003). Immunohistochemical Staining of benign fibrocystic disease was positive for ER and PR. Tubulopapillary carcinoma positive for ER and PR Anaplastic giant carcinoma was negative for ER positive for PR. Mucinus adenocarcinoma was positive for ER negative for PR. Complex carcinoma was positive for ER and negative PR. Mixed carcinoma was negative for PR and ER Ravaioli et al. (1998). Millanta et al. (2006) reported incidentally, significantly lower PR expression in malignant tumors. Most of the lesions with low PR immunoreactivity and ER negativity were mixed carcinoma.

Previous studies showed a decreasing percentage of ER and PR immunoreactivity with increasing malignancy to the fact that, the degree of cellular proliferation seems to influence the receptor expressions where rapidly proliferated cells contained fewer receptors as hormonal sensitivity is lost as well as tissue antigenicity Moreover, our findings were supported by the concept of Hoskins et al. (2005) who explored that ER have been positively correlated with histological differentiation and it is used as adiagnostic discriminate. Tumors that metastasize were frequently negative for ER (Nieto et al., 2000; Millanta et al., 2006; Martin et al., 2005 and Yang et al., 2006). In previous study, ER, PR or both receptors positively stained represented differences among severity and histological subtypes of canine mammary tumors (Martin et al., 2005). Thuroczy et al. (2007) revealed that proliferation index of malignant tumors were higher than benign tumors and dysplastic conditions. Even though the literature showed that being positive for estrogen receptors may result in good prognosis (Silva 2004). However, even small immunohistochemical studies may contribute to finding of prognostic markers that will eventually improve diagnosis and treatment of canine mammary tumors. ER and PR expression epithelial cells is considered a marker for risk of developing breast cancer and for preventive intervention (Fabian et al., 2005 and Ferretti et al., 2007).

Factors for poor prognosis were size of tumor, lymph node involvement, ulcerated tumor surface, rapid growth of tumor, tumor adherence to deeper tissues and nuclear differentiation (Dobson et al., 2003). Dogs with simple carcinomas had a worse prognosis than with other carcinomas as noted in many of the studies, lymphatic/vascular invasion and lymph node metastasis was expected to be associated with a poor prognosis (Goldschmidt et al., 2011).

\section{CONCLUSION}

To the best of our knowledge, serum values of CA 15-3 mammary tumor marker were determined in normal healthy, diseased non tumor bearing, and tumor bearing dogs for the first time in local reared mixed breeds of dogs in Egypt.

Serum CA 15-3 values were correlated with mammary tumor development in dogs.

This study indicated some information about histopathlogical types of mammary tumour combined with immunohistochemical staining of estrogen receptors (ER) and progesterone receptors $(\mathrm{PR})$ in canine mammary gland tumors. Immunohistochemical technique have critical role and may allow accurate diagnosis of canine mammary tumors. So, this research work may provide the basis for developing a novel approach in veterinary research. Additional studies using a large number of healthy and pathological clinical samples to revalidate these findings are strongly recommended.

\section{REFERANCES}

Al-Azawi, D.; Kelly, G.; Myers, E.; McDermott, E.W.; Hill, A.D.; Duffy, M.J. and Higgins, NO. (2006): CA $15-3$ is predictive of response and disease recurrence following treatment in locally advanced breast cancer BMC Cancer, 6:220.

Bablok, W.; Passing, H. and Bender, R. (1988): A general regression procedure for method transformation. Application of linear regression procedures for method comparison studies in clinical chemistry, part 111. J. Clin. Chem. Clin. Biochem. Nov.: 26(11): 783-790.

Bancroft, J.D.; Stevens, A. and Turner, D.R. (1996): Theory and practice of histological techniques 4th ed. Churchill Living Stone, New York Edinburgh Madrid, San Francisco, Tokyo.

Batemam, A.C. (2006): Pathology of benign breast disease. wohm Doi: 10.1383 .

Bergman, J.P. (2003): Clinical techniques in small animal molecular oncology. Clinical 
Techniques in Small Animal Practice, 18, 88-91.

Breen, M. (2009): Update on genomics in veterinary oncology. Top Companion Anim Med 24(3), 113-21.

Campos, L.C.; Lavalle, G.E.; Estrela-Lima, A. and Melgaço de Faria, JC. (2012): CA15.3, CEA and LDH in dogs with malignant mammary tumors. J. Vet. Intern. Med. 26(6):1383-8.

Childress, M.O. (2012): Hematologic abnormalities in the small animal cancer patient. Vet. Clin. North Am Small Anim Pract. Jan.; 42(1): 123-55.

Collins, L.C. and Schnitt, S.J. (2008): Papillary lesions of the breast: Selected diagnostic and management issues. Histophathol. 52: 20-29.

Dacie, J.V. and Lewis, S.M. (1977): Practical Hematology. 5th. ed. Elbsand Churchill, living stone.

Da Costa, A.; Lenze, D.; Hummel, M.; Kohn, B.; Gruber, A.D. and Klopfleisch, R. (2012): Identification of Six Potential Markers for the Detection of Circulating Canine Mammary Tumour Cells in the Peripheral Blood Identified by Microarray Analysis. Journal of Comparative Pathology Vol. 146, Iss2-3, 143-151.

Dobson, J.M.; Duncan, B. and Lascelles, X. (2003): BSAVA manual of canine and feline oncology. 2nd ed. Gloucester, UK: British Small Animal Veterinary Association 234-242.

Doumas, B.T.; Bayso, D.D.; Carter, R.J.; Peter, T.Jr. and Schffer, R. (1981): A candidate reference method for determination of total protein in serum. I. Development and validation. Clin. Chem. 27(10): 1642-1650.

Doumas, B.T.; Walson, W.A. and Biggs, H.G. (1971): Albumin standards and measurement of serum albumin with bromocrysol green. Clin. Chim. Acta. 31(1): 87-96.

Duffy, J.; Duggan, C.; Keane, R.; Hill, A.D.K.; McDermott, E.; Crown, J. and O'Higgins, N. (2004): High preoperative CA 15-3 concentrations predict adverse outcome in node-negative and node-positive breast cancer: study of 600 patients with histologically confirmed breast cancer. Clin. Chem., 50: $559-563$.

Duffy, J. (2006): Serum Tumor Markers in Breast Cancer: Are They of Clinical Value? Clinical Chemistry vol. 52 no. 3 345-351.

Fabian, C.J.; Kimler, B.F.; Mayo, M.S. and Khan, S.A. (2005): Breast-tissue sampling for risk assessment and prevention. Endocr Relat Cancer 12: 185-213.

Feldman, B.F.; Zinkl, J.G. and Jain, V.C. (2000): In Schalm's Veterinary hematology. 5th. ed. Lippincott Williams \& Wilkins, Canada, P. 1145-1146.
Ferretti, G.; Felici, A.; Papaldo, P.; Fabi, A. and Cognetti, F. (2007): HER2/neu role in breast cancer: from a prognostic foe to a predictive friend. Curr. Opin. Obstet. Gynecol. 19:56-62.

Gama, A.; Alves, A.; Gartner, F. and Schmitt, F.C. (2003): A novel myoepithelial cell marker in canine mammary tissues. Vet. Pathol., 40: 412-420.

Goldschmidt, M.; Pena, L. and Rasotto, R. (2011): Classification and grading of canine mammary tumors. Vet. Pathol. 48(1): 117-131.

Guillot, E.; Couturaud, B.; Reyal, F.; Curnier, A. and Ravinet, J. (2011): Management of Phyllodes Breast Tumors. The Breast Journal., 17(2): 129-137. The Breast Journal, 17(2): 129-137.

Guray, M. and Sahin, A.A. (2006): Surgical and Clinical Pathology of Breast Diseases oncologist, 11, 435-449.

Hartman, L.; Sellers, A.; Frost, H.; Lingle, W.; Degnim, A. and Ghosh, K. (2005): Benign breast disease and the risk of breast cancer. $\mathrm{N}$. J. Med. 35: 229-237.

Hayes, D.F.; Sekine, H.; Ohno, T.; Abe, M.; Keefe, K. and Kufe, D.W. (1985): Use of a murine monoclonal antibody for detection of circulating plasma DF3 antigen levels in breast cancer patients. J. Clin. Invest., 75: 1671-1678.

Hoffbrand, A.V.; Catovsky, D. and Edward, G.D. (2005): Postgraduate Haematology, Fifth Edition Tuddenham Copyright (C) Blackwell Publishing.

Hoskins, W.; Perez, C.; Young, C.; Barakat, R.; Markman, M. and Randall, M. (2005): Principals and practice of Gynecologic 4th Edition Chap. 23. corpus. Epithelial tumours. Lippicott William \&Wilkins Awolters Klumer comp.

Hsu, W.L.; Huang, H.M.; Liao, J.W.; Wong, M.L. and Chang, S.C. (2009): Increased survival in dogs with malignant mammary tumors over expressing HER-2 protein and detection of a silent single nucleotide polymorphism in the canine HER-2 gene. Vet. J. 180, 116-123.

Husdant, H. and Rapaport, A. (1958): Estimation of creatinine. Clin. Chem., 14: 222.

Itoh, H.; Yutaka, H. and Teppei, N. (2009): Evaluation of immunological status in tumorbearing dogs Vet. Immunology and Immunopathology 132 85-90.

Jain, S. (1993): Essentials of Haematology, Lea and Febiger, Philadelphia. Pp.

Karlsson and Lindblad-Toh, (2008): Leader of the pack: gene mapping in dogs and other model organisms. Nat Rev Genet 9(9), 713-25.

Kruth, S.A. and Carter, R.F. (1990): Laboratory abnormalities in patients with cancer. Vet. Clin. North Am Small Anim Pract. Jul: 20(4): 897-917.

Kurilj, A.; Marko, H.; Branka, A.; Kresimir, S.; Ivan, C. and Sostaric, Z. (2011): Histopathological 
evaluation and immunohistochemical study of estrogen receptor $\alpha$, HER-2 and $\mathrm{Ki}-67$ in canine neoplastic mammary lesions Veterinarski Arhiv 81 (6), 709-722.

Lana, S.E.; Rutteman, G.R. and Withrow, S.J. (2007): Tumors of the mammary gland. In: Small Animal Clinical Oncology. (Withrow, S. J., D. M. Vail, Eds.). Saunders, Elsevier. St. Louis, Missouri. pp. 619-636.

Ledecky, V.; Valencakova-Agyagosova, A.; Lepej, J.; Frischova, Z.; Hornak, S. and Nagy, V. (2013): Determination of carcinoembryonic antigen and cancerantigen values with the radioimmunoassay method in healthy females dogs. Veterinarni Medicina, 58, (5): 277-283.

Leong, A.S. Cooper, K. and Leong, J.F. (2003): Manual of diagnostic antibodies for immunohistology 2nd edition Greenish medical media Ltd.

Manuali, E.; De Giuseppe, A.; Feliziani, F.; Forti, K.; Casciari, C.; Marchesi, M.C.; Pacifico, E.; Pawłowski, K.M.; Majchrzak, K. and Król, M. (2012): CA 15-3 cell lines and tissue expression in canine mammary cancer and the correlation between serum levels and tumor histological grade. BMC Vet. Res. 22: 80-86.

Mart'ın de las Mulas, J.; Millan, Y. and Dios, R. (2005): A prospective analysis of immunohistochemically determined estrogen receptor alpha and progesterone receptor expression and host and tumor factors as predictors of disease-free period in mammary tumors of the dog. Vet. Pathol. 42: 200-212.

Matharoo-Ball, B.; Miles, A.K.; Creaser, C.S.; Ball, $G$. and Rees, R. (2008): Serum biomarker profiling in cancer studies: a question of standardisation? Vet. Comp Oncol. Dec.; 6(4): 224-47.

Millanta, F.; Silvestri, G. and Vaselli, C. (2006): The role of vascular endothelial growth factor and its receptor FlK- $1 / \mathrm{KDR}$ in promoting tumor angiogenesis in feline and canine mammary carcinomas: a preliminary study of autocrine and paracrine loops. Res. Vet. Sci. 81(3): 350-357. 25.

Misdorp, W.; Cotchin, E. and Hampe, J.F. (1972): Canine malignant mammary tumors: II. Adenocarcinomas, solid carcinomas and spindle cell carcinomas. Vet. Pathol. 9(6): 447-470.

Misdorp, W.; Cotchin, E. and Hampe, J.F. (1973): Canine malignant mammary tumors: III. Special types of carcinomas, malignant mixed tumors. Vet. Pathol. 10(3): 241-256.

Misdorp, W. (2002): Tumors of the mammary gland. In: Meuten DJ. Tumors in domestic animals. 4th ed. Ames, USA: Iowa State Press 575-606.

Misdorp, W.; Else, R.W. and Hellmen, E. (1999): Histological classification of mammary tumors of the dog and the cat. 2nd ed. Washington,
USA: Armed Forces Institute of Pathology; 3-29.

Molina, R.; Barak, V.; Van Dalen, A.; Duffy, M.J.; Einarsson, R.; Gion, M.; Goike, H.; Lamerz, R.; Nap, M.; Sölétormos, G. and Stieber, P. (2005): Tumor markers in breast cancer. European Group on Tumor markers recommendations. Tumour Biol, 26: 281-293.

Nieto, A.; Pena, L. and Perez-Alenza, M.D. (2000): Immunohistologic detection of estrogen receptor alpha in canine mammary tumors: Clinical and pathological associations and prognostic significance. Vet. Pathol. 37: 239-247.

Patsikas, M.; Karayannopoulou, M.; Kaldrymidoy, E.; Papazoglou, L. and Papadopoulou, P. (2006): The lymph drainage of the neoplastic mammary glands in the bitch: A lymphographic study. Anat Histol Embryol 35: 228-234.

Patton, M.P. and Crouch, S.R. (1977): Determination of Urea (Urease modified Berthelot reaction) Anal. Chem. 49: 464-469.

Pena, L.; Perez-Alenza, M.; Rodriguez-B. and Nieto, A. (2003): Canine inflammatory mammary carcinoma: histopathology, immunohistochemistry and clinical implications of 21 cases. Breast Cancer Res. Treat. 78: 141-148.

Pereira, C.; Rahal, S.; De Carvalho Balieiro, J. and Ribeiro, A. (2003): Lymphatic drainage on healthy and neoplasic mammary glands in female dogs: can it really altered. Anat. Histol. Embryol. 32: 282-290.

Perey, L.; Hayes, D.F.; Maimonis, P.; Abe, M.; O’Hara, C. and Kufe, D.W. (1992): Tumor selective reactivity of a monoclonal antibody prepared against a recombinant peptide derived from the DF3 human breast carcinomaassociated antigen. Cancer Res., 52: 2563-2568.

Peyman, S.; Mohammad, A.T. and Mohammad, H.D. (2013): Phyllodes Tumor of Mammary Gland in a Dog: Case Report.

Pinder, S.E. (2010): Surgical and Clinical Pathology of Breast Diseases. Mod. Pathol. 235-813.

Pulley, L.T. (1973): Ultrastructural and histochemical demonstaration of myoepithelium in mixed tumors of the canine mammary gland. Am. J. Vet. Res. 34: 1513-1522.

Ravaioli, A.; Bagli, L.; Zucchini, A. and Monti, F. (1998): Prognosis and prediction of response in breast cancer: the current role of the main biological markers. Cell Prolif. 31:113-26.

Reitman, S. and Frankels, S. (1957): A colormetric Method for determination of serum Glutamic Oxaloacetic transaminase and serum Glutamic pyruvic transaminase. Am. J. Clin. Pathol., 25-56. 
Rivera, P. (2010): Biochemical Markers and Genetic Risk Factors in Canine Tumors. Ph.D., thesis Faculty of Veterinary Medicine and Animal Science, Department of Clinical Sciences, Swedish University of Agricultural Sciences, Acta Universitatis Agriculturae Sueciae :34 ISSN 1652-6880, ISBN 978-91-576-7447.

Rosai, J. (2011): Rosai and Ackerman's surgical pathdogy: $10^{\text {th }}$ edition Elsevier., Vol. 2: 1673-1710.

Rosen, P.P. (2009): Rosen's breast pathology: $4^{\text {th }}$ edition Lippincott Williams., 469-611.

Seker, D.; Kaya, O.; Adabag, A.; Necipoglu, G. and Baran, I. (2003): Role of preoperative plasma CA 15-3 and Carcinoembryonic antigen levels in determining histopathologic conventional prognostic factors for breast cancer. World J. Surg, 27: 519-521.

Silva, A.E.; Serakides, R. and Cassali, G.D. (2004): Carcinogênese hormonal neoplasias hormôniodependentes. Ciência Rural 34: 625-633.

Stockham, L. and Scott, A. (2002): Fundamental of veterinary clinical pathology. Lowa State Press, first edition, A Blackwell Puplishing Company.

Sutter, N.B.; Bustamante, C.D.; Chase, K.; Gray, M.M.; Zhao, K.; Zhu, L. and Padhukasahasram, B. (2007): A single IGF1 allele is a majordeterminant of small size in dogs. Science 316 (5821), 112-5.

Sutter, N.B. and Ostrander, E.A. (2004): Dog star rising: the canine geneticsystem. Nat. Rev. Genet. 5(12): 900-10.
Thrall, M.A.; Campbell, T.W.; De Nicola, D.; Fettman, M.J.; Lassen, E.D.; Rebar, A. and Wieser, G. (2004): Veterinary Hematology and Clinical Chemistry. Lippincott Williams \& Wilkins., A walters Kluwer Company., Philadelphia, Baltemore, New York, London.

Thuroczy, J.; Reisvaag, G.J.K.; Perge, E.; Tibold, A.; Szilagyi, J. and Balogh, L. (2007): Immunohistochemical detection of progesterone and cellular proliferation in canine mammary tumours. J. Comp. Pathol. 137, 122-129.

Tonitil, W.; Shutipen, B.; Areerat, K.; Phingpol, C.; Pranom, P. and Chaiyan, K. (2009): Immunohistochemical determination of estrogen and progesterone receptors in canine mammary tumors Asian Pacific Journal of cancer prevention, Vol. 10, 907-911.

Vankampan, E.J. and Zijlistra, W.G. (1961): Estimation of hemoglobin. Clin. Chem. Acta, 6: p 538.

Yang, W.Y.; Liu, C.H.; Chang, C.J.; Lee, C.C.; Chang, K.J. and Lin, C.T. (2006): Proliferative activity, apoptosis and expression of oestrogen receptor and $\mathrm{Bcl}-2$ oncoprotein in canine mammary gland tumours. J. Comp. Pathol. 134: 70-9.

Zuccari, D.A.; Santana, A.E. and Rocha, N.S. (2002): Expression of intermediate filaments in canine mammary tumor diagnosis. Arq. Bras. Med. Vet. Zootec., 54, 586-91.

\title{
التغيرات الهيماتولوجية والبيوكيميائية وارتباطها بالتغيرات الهستوباثولوجية والعلامات البيولوجية بالسيرم في الكلاب

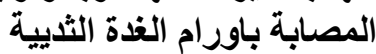

\author{
شاهيناز محمد حسين ، ناهد فتحي زغلول ، سناء عبله الشامح ، دينا كمال لطيف \\ Email: afyfi@yahoo.com Assiut University web-site: www.aun.edu.eg
}

\begin{abstract}
الاور ام من الامر اض المنتشرة في الانسان و الحيوان وخصوصا اور ام الثدي ولكن بو اسطة التشخيص السريع بعدة طرق يتم مجابهة

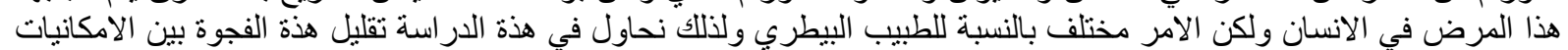

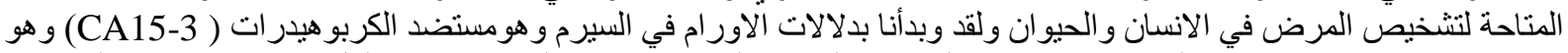

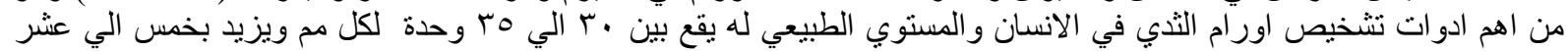

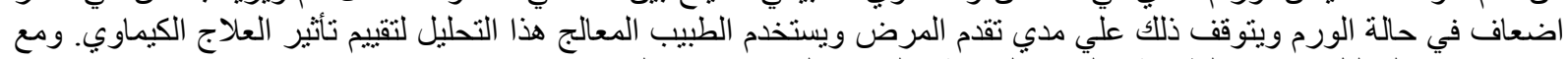

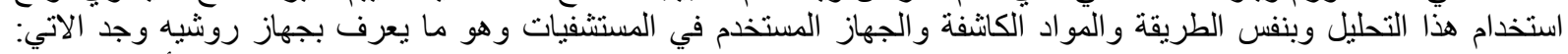

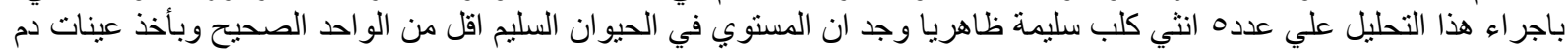

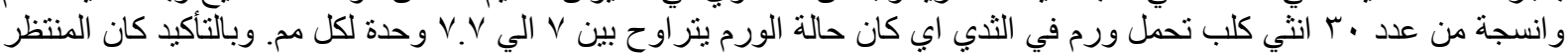

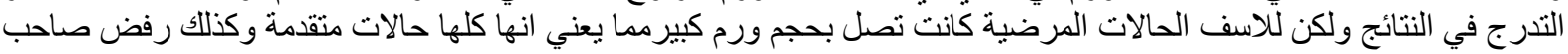

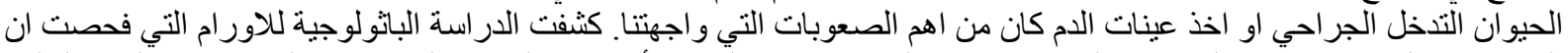

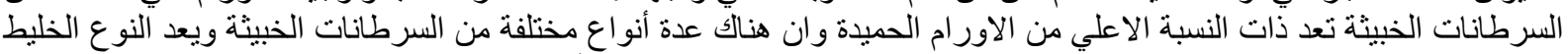

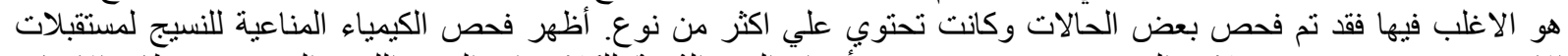

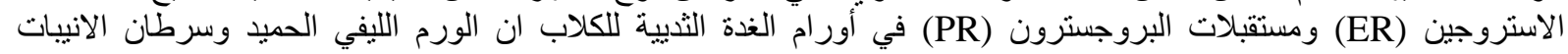

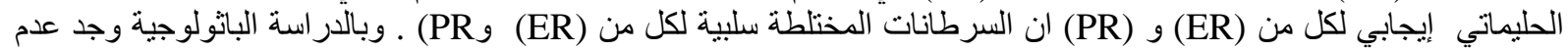

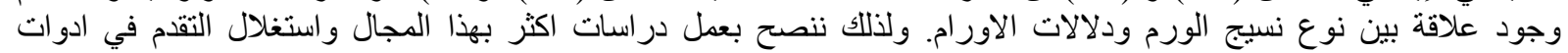

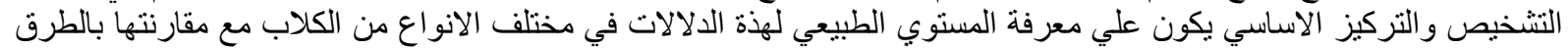
المختلفة المستخدمة ومحاولة التغيير في الطريقة المستخدم بها التحليل للوصول لنتيجة احسن مع العلم النه سيحتاج لوقت ومجهود كبير.
\end{abstract}

